\title{
Acquired resistance to aromatase inhibitors: where we stand!
}

\author{
Tiago Vieira Augusto', Georgina Correia-da-Silva', Cecília M P Rodrigues ${ }^{2}$, Natércia Teixeira$^{1}$ and $^{1}$ Cristina Amaral $^{1}$
}

1UCIBIO.REQUIMTE, Laboratory of Biochemistry, Department of Biological Sciences, Faculty of Pharmacy, University of Porto, Porto, Portugal

${ }^{2}$ Research Institute for Medicines (iMed.ULisboa), Faculty of Pharmacy, University of Lisbon, Lisbon, Portugal

Correspondence should be addressed to C Amaral: cristinamaralibd@gmail.com

\begin{abstract}
Aromatase inhibitors (Als) are one of the principal therapeutic approaches for estrogen receptor-positive $\left(E R^{+}\right)$breast cancer in postmenopausal women. They block estrogen biosynthesis through aromatase inhibition, thus preventing tumour progression. Besides the therapeutic success of the third-generation Als, acquired resistance may develop, leading to tumour relapse. This resistance is thought to be the result of a change in the behaviour of ER in these breast cancer cells, presumably by PI3K/AKT pathway enhancement along with alterations in other signalling pathways. Nevertheless, biological mechanisms, such as apoptosis, autophagy, cell cycle modulation and activation of androgen receptor (AR), are also implicated in acquired resistance. Moreover, clinical evidence demonstrated that there is a lack of cross-resistance among Als, although the reason is not fully understood. Thus, there is a demand to understand the mechanisms involved in endocrine resistance to each $\mathrm{Al}$, since the search for new strategies to surpass breast cancer acquired resistance is of major concern.
\end{abstract}

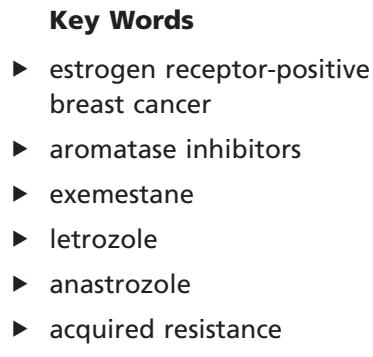

Endocrine-Related Cancer (2018) 25, R283-R301

\section{Estrogen-dependent breast cancer}

In women, breast cancer is both the most common cancer worldwide and the second cause of cancer death (Cardoso et al. 2017). Approximately $60 \%$ of premenopausal and $75 \%$ of postmenopausal breast cancer patients have estrogen receptor-positive $\left(\mathrm{ER}^{+}\right)$carcinomas. ER expression and activation are important factors to control tumour growth and recurrence (Chen 2011). Although there are several therapeutic approaches, endocrine therapy has become the standard adjuvant treatment for postmenopausal women with $\mathrm{ER}^{+}$breast cancer (Cardoso et al. 2017). Drugs that selectively target ER, like the selective ER downregulators (SERDs), such as fulvestrant, or the selective ER modulators (SERMs), such as tamoxifen or drugs that prevent estrogen biosynthesis, like AIs, are important therapeutic tools to block the ER signalling pathways that lead to cancer progression.
Over the last decade, AIs have been considered as firstline therapy for postmenopausal women with $\mathrm{ER}^{+}$breast cancer (Cardoso et al. 2017). In fact, AIs therapy presents higher clinical efficacy, prolonged disease-free survival and time to recurrence, and significantly less severe side effects than tamoxifen. Nevertheless, clinical trials generally suggest that AIs therapy does not significantly improve overall survival when compared to tamoxifen therapy (Bonneterre et al. 2001, Mouridsen et al. 2001, 2003, Milla-Santos et al. 2003, Paridaens et al. 2004, 2008, Howell et al. 2005, Chumsri 2015, Early Breast Cancer Trialists' Collaborative Group 2015). This unintended effect on overall survival may be associated with immature data from many studies, which report an increase in the number of non-cancer deaths in patients with prolonged AI therapy, and, consequently, this increase attenuates the 
contribution of the treatment in reducing the number of breast cancer deaths (Goldvaser et al. 2018).

In relation to fulvestrant, it is clear that AIs are nonsuperior in terms of efficacy and tolerability. Clinical data suggests that, in some cases, fulvestrant may increase progression-free survival and overall survival when compared to AIs (Robertson et al. 2009, 2012, 2016, Ellis et al. 2015). Despite this, its poor solubility impairs its oral delivery to the patients, meaning that the administration must be performed by intramuscular injection. This drawback limited its clinical use as first-line therapy in the adjuvant setting. Therefore, the development of new orally available SERDs is a growing field that might strengthen the use of this class of drugs, in the future, for the adjuvant setting (Lai et al. 2015, Liu et al. 2016, Zhang et al. 2017). In fact, there are several oral SERDs that are being studied in clinical trials as the phase I/II non-randomised study of GDC-0810 (NCT01823835), the dose-escalation phase I trials of AZD9496 (NCT02248090) and of RAD1901 (NCT02338349) (Vries et al. 2016, Bardia et al. 2017). For these reasons, AIs remain the goldstandard treatment option in postmenopausal $\mathrm{ER}^{+}$breast cancer therapy due to their improved clinical efficacy and manageable toxicity profile. Moreover, in recent years, AIs have begun to be administered in drug combinations that will be mentioned throughout this review.

\section{Aromatase inhibitors}

Human aromatase belongs to the cytochrome P450 family and is the product of the CYP19A1 gene on chromosome 15. Aromatase is the only known enzyme in vertebrates that, through the aromatization of the A-ring of androgens, catalyses the biosynthesis of estrogens (estradiol and estrone) from the androgenic precursors (testosterone and androstenedione) (Ghosh et al. 2012). Ghosh et al. using $\mathrm{X}$-ray crystallography solved the structure of aromatase and its enzyme-substrate interaction (Ghosh et al. 2009, 2010). The elucidation of the active site of aromatase gave new insights for the design and discovery of novel AIs (Ghosh et al. 2016).

AIs are a specific class of drugs that deplete the levels of circulating estrogens by inhibiting aromatase. According to AIs chemical structure, they are classified into two subtypes, steroidal (Type I) and non-steroidal (type II). Steroidal AIs compete with the natural substrate of the enzyme, binding covalently to the active site, which results in irreversible inhibition. These AIs are known as suicidal inhibitors because after the enzyme is inactivated, it is degraded by the proteasomes. In contrast, type II AIs bind non-covalently to the heme moiety of aromatase and saturate its active site. Unlike type I inhibition, type II inhibition is reversible (Chumsri 2015, Sobral et al. 2016). AIs can also be grouped in three generations, according to their chronological order of appearance in clinic. The first AI used for breast cancer treatment, in the late 1970s, was a former anti-epileptic drug, the non-steroidal aminoglutethimide (Griffiths et al. 1973). However, as aminoglutethimide inhibited not only aromatase but also another cytochrome P450 enzyme, CYP11, which is involved in the conversion of cholesterol to pregnolone, a replacement therapy with glucocorticoids was necessary (Santen 1981). Subsequently, second-generation AIs were developed during the 1980s and 1990s, with the most prominent drugs being the steroidal formestane (4-hidroxyandrostenedione, 4-OHA) (Brodie et al. 1977) and the non-steroidal imidazole, fadrozole (CGS16949A) (Schieweck et al. 1988). Both second-generation AIs were more potent than aminoglutethimide, though, their use in clinic was not attractive since fadrozole had a short half-life and also suppressed cortisol and aldosterone biosynthesis (Demers et al. 1990), whereas formestane had poor biological activity when administered orally and had to be delivered by intramuscular injection (Dowsett \& Coombes 1994). In the current third-generation, the nonsteroidal AIs are derived from imidazole (anastrozole and letrozole), while the steroidal AI (exemestane) resulted from modifications in the structure of androstenedione, the natural substrate of aromatase. This generation of AIs is used in adjuvant treatment for early and metastatic stage, as first-line treatment options for postmenopausal patients (Cardoso et al. 2017). Nevertheless, more recently, due to the results from clinical trials, such as Suppression of Ovarian Function Trial (SOFT) (NCT00066690), AIs are also being considered for premenopausal women with suppressed ovarian function (Pagani et al. 2014, Regan et al. 2015).

Behind its therapeutic success, different clinical trials demonstrate that prolonged therapy with AIs can cause adverse effects. Several clinical trials that compared AIs with tamoxifen therapy indicate that AIs are associated with decreased incidence of hot flushes and gynecologic and thromboembolic side effects, but increased skeletal complications, musculoskeletal pain, arthralgia, cardiovascular events and sexual dysfunction (Nabholtz 2008, Amir et al. 2011, Khosrow-Khavar et al. 2017). Nevertheless, these trials have limited power to evaluate accurately the effect of AIs on safety and tolerability, as the current knowledge is based on data that compared AIs with tamoxifen, with the toxicity profile of AIs being unclear 
when compared with the no treatment group. Recently, a meta-analysis study from randomised controlled trials that compared AIs to placebo or to no treatment groups supported the fact that extended AIs therapy is associated with an increased risk of cardiovascular events and bone fractures (Goldvaser et al. 2018). Clinical trials that compare AIs therapy with tamoxifen also suggest that AIs lack the cardioprotective effects pointed to tamoxifen (Nabholtz 2008, Amir et al. 2011). Although the effect of mechanism of AIs on cardiovascular morbidity is unclear, it has been reported that AIs increase risk factors such as dyslipidemia, artherial hypertension and accelerated atherosclerosis (Nathan et al. 2001, Mouridsen et al. 2007, Nabholtz 2008, Amir et al. 2011, Goldvaser et al. 2018).

The decrease in circulating estrogen levels induced by AIs may lead to bone mineral loss and osteoporotic fractures (Morales et al. 1996, Williams et al. 1997, Reis et al. 2001, Aapro 2004). Several clinical trials that compare AIs with tamoxifen therapy showed a statistically significant higher risk of bone fractures in patients treated with AIs (Nabholtz 2008, van de Velde et al. 2011, Early Breast Cancer Trialists' Collaborative Group 2015, Sobral et al. 2016). Nevertheless, the impact of AIs on bone health can be attenuated, by the association of AIs with bisphosphonates, such as zoledronic acid or risedronate (Brufsky et al. 2012, Greenspan et al. 2015), or denosumab, a monoclonal antibody that inhibits Receptor Activator of Nuclear Factor $\kappa B$ (RANK) and modulates osteoclast activity (Gnant et al. 2015). In addition, despite the general therapeutic index of AIs suggesting superiority over tamoxifen with proven improved efficacy and better toxicity profile (Nabholtz 2008, Cardoso et al. 2017, Goldvaser et al. 2018), the prolongation of treatment with AIs or with anti-estrogens may promote the occurrence of endocrine resistance, this being considered the major concern in breast cancer therapy.

\section{Genomic and non-genomic estrogen receptor pathways}

ER is a nuclear receptor involved in the regulation of many physiological processes in humans. This receptor has two isoforms, ER $\alpha$ and ER $\beta$, which share a 59\% homology. The former is located on chromosome 6 , while the latter is on chromosome 14 (Heldring et al. 2007, Jia et al. 2015). Both ERs contain a DNA-binding domain (DBD), a dimerization region (DR), a ligand-binding domain (LBD) and two transactivation domains. One of these domains is located near the N-terminus (AF-1) and is activated through phosphorylation of serine 167, by PI3K/AKT (Campbell et al. 2001), and/or of serine 118, by RAS/MAPK (Kato et al. 1995, Bunone et al. 1996), in a ligand-independent manner and by CDK7 (Chen et al. 2000, 2002), in a ligand-dependent manner. The other transactivation domain is located near the C-terminus (AF-2) and is activated through binding to estradiol $\left(\mathrm{E}_{2}\right)$. Despite the high sequence homology in the DBD between the two isoforms of ER, they are not redundant genes, since they have different expression patterns and functions (Chan et al. 2016). ERo has been associated with growth and survival of tumour and non-tumour breast epithelial cells, while ER $\beta$ is associated with growth inhibitory properties, by arresting cell cycle progression of breast cancer cells (Paruthiyil et al. 2004, Chan et al. 2016).

Within the cytosol, ER is bound through LBD (AF-2) to chaperone proteins, such as heat shock protein 90 (HSP90) and HSP70, which are essential to maintain the ER in an inactivated form (Htun et al. 1999, Pick et al. 2007, Chan et al. 2016). Upon binding of estrogens to ER, the receptor undergoes conformational changes, like the dissociation from the HSP and subsequent dimerization. This allows the translocation of ER to the nucleus, in order to bind estrogen-responsive elements (ERE) in the promoter region of ER-regulated genes and the recruitment of co-activators to initiate classical genomic transcriptional modulation. The ER can also interact with other transcription factors such as activator protein 1 (AP-1) to bind DNA indirectly, leading to the modulation of target genes located at alternative responsive elements in a process known as non-classic or ERE-independent genomic action. Besides these two different mechanisms of genomic action, a third mechanism exists. It involves the ligand-independent activation of ER through phosphorylation of the AF-1 domain by several kinases of the growth factor receptors signalling pathways, like p38, p44/42 or PI3K/AKT (Bunone et al. 1996, Chan et al. 2016). This ligand-independent activation is a process that often leads do endocrine resistance (Kato et al. 1995, Swaby \& Jordan 2008). In addition to the genomic pathways, there are rapid effects that do not rely on transcriptional activity and are triggered through growth factor receptors (GFRs), namely fibroblast growth factor receptor 1 (FGFR1) (Turner et al. 2010, Andre \& Cortes 2015), insulin-like growth factor 1 receptor (IGF1R) (Stephen et al. 2001, Fox et al. 2011), epidermal growth factor receptor (EGFR), human epidermal growth factor receptor 2 (HER2) (Mehta \& Tripathy 2014, Flageng et al. 2017), other membrane receptors, like G-protein-coupled ER (GPR30) (Scaling et al. 2014, Kim et al. 2015), and ER variants (Li et al. 2003, Chaudhri et al. 2014). These are 
the non-genomic pathways and consist of activating several kinases signalling pathways like PLC/PKC, RAS/RAF/MAPK and cAMP/PKA or even in the release of several cyclic nucleotides (cAMP, cGMP) and calcium (Chan et al. 2016). The activation of these signalling pathways may indirectly connect non-genomic actions of estrogens to genomic responses, since many transcription factors are regulated by protein kinases, making these transcription factors the main targets for the non-genomic actions of estrogens.

\section{Endocrine therapy resistance}

As previously referred to, estrogen deprivation has been considered an important treatment for estrogendependent $\left(\mathrm{ER}^{+}\right)$breast cancers. However, 20\% of patients with early-stage disease are unresponsive to therapy (Early Breast Cancer Trialists' Collaborative Group 2011) and, despite the initial benefit, some patients with metastatic breast cancer may experience tumour progression, being in these cases, the 5-year survival rate of around $26 \%$ and the overall average survival between 2 and 3 years (Cardoso et al. 2017).

Resistance to AIs is divided into two main types: primary/de novo resistance and secondary/acquired resistance. Recently, ESO-ESMO international consensus guidelines for advanced breast cancer defined the primary resistance as a relapse during the first 2 years of adjuvant endocrine therapy or progression of disease within the first 6 months of first-line endocrine therapy for metastatic breast cancer. Secondary/acquired resistance is defined as a relapse while on adjuvant endocrine therapy but after the first 2 years, or as a relapse within 12 months of completing adjuvant endocrine therapy, or progression of disease after 6 months of initiating endocrine therapy for metastatic breast cancer (Cardoso et al. 2017). Although the clinical distinction between the two types of resistance is not yet well defined, the mechanisms underlying these two types of resistance are likely to overlap.

Tyson et al. reviewed different mathematical models that integrate the biological systems of endocrine responsiveness in $\mathrm{ER}^{+}$breast cancer, leading to the identification of key molecules that may control the response of breast cancer cells to endocrine therapy (Tyson et al. 2011). Curiously, by analysing information about the genetic, molecular biology and physiology of cancer cells, the models allocate the key molecules that were associated to the development of AIs resistance, both in vitro and in vivo, in 'decision modules' (cell cycle and apoptosis), 'stress modules' (autophagy and unfolded protein response) and 'signal processing modules' (ER and growth factor signalling).

As the majority of acquired endocrine resistance cases occur in ER-expressing breast cancers, it is suggested that loss of ER expression is not the main mechanism. This evidence reinforces the need to understand the molecular processes in order to design new strategies to overcome AIs-acquired resistance. In this review, only the main mechanisms associated with acquired resistance will be explored, beginning by generally describing the overall mechanisms and the specific pathways for each AI.

\section{Estrogen-related gene mutations}

The gene estrogen receptor 1 (ESR1) encodes ER $\alpha$ and its mutations have been proposed as a mechanism of AIs resistance since the early 1990s (Fuqua et al. 1991). This hypothesis was initially underappreciated because mutations in this gene were rare in treatment-naïve primary tumours (Roodi et al. 1995). In fact, it was detected that only around 3\% of the primary tumours from BOLERO-2 clinical trial presented ESR1 mutations (Toy et al. 2013, Jeselsohn et al. 2015). However, different studies demonstrated that these mutations appear with higher frequencies, ranging from 11 to $55 \%$ in metastatic tumours, especially in those that have progressed despite AI treatment (Robinson et al. 2013, Jeselsohn et al. 2015, Schiavon et al. 2015, Chandarlapaty et al. 2016, Angus et al. 2017). The most common point mutations in this gene occur specifically in the LBD encoding domain, like Y537S/N/C and D538G (Niu et al. 2015). These mutations can confer estrogen-independent ER activation, through recruitment of co-activators and stabilization of the agonist (Fanning et al. 2016). This process often leads to an estrogen-independent cell proliferation (Robinson et al. 2013, Toy et al. 2013). Several trials tried to assess the clinical impact of these mutations and data suggested that they may influence the clinical outcome in metastatic setting. Accordingly, in the SoFEA clinical trial and in the BOLERO-2 trial, patients who were treated with exemestane and harboured ESR1 mutation presented a decrease in the progression-free survival when compared with wild-type ESR1 patients treated with exemestane (Chandarlapaty et al. 2016, Fribbens et al. 2016).

ESR1 chromosomal translocation is another described mechanism where several in-frame fusion genes that preserve the first exons, including the DBD domain, are spliced in-frame into the C-terminus of other genes. Examples of these genes are Yes-associated protein 1 (ESR1-YAP1), DNA-polymerase $\eta$ (ESR1-POLH), A kinase 
anchor protein 12 (ESR1-AKAP12) and coiled-coil domain containing 170 (ESR1-CCDC170) (Li et al. 2013, Ma et al. 2014). ESR1-YAP1 is the best documented translocation, and in this case, YAP1 sequences mimic the liganddependent transactivation domain (AF-2), inducing estradiol-independent growth and ER-regulated gene transcription (Li et al. 2013). CCDC170 is only separated from ESR 1 by $69 \mathrm{~kb}$. Fusion events of these two genes join the promoter regions of the ESR 1 and of the CCDC170 genes, generating a fusion protein that corresponds to $\mathrm{N}$-terminal truncated forms of CCDC170 ( $\triangle C C D C 170)$. This fusion protein renders more aggressive luminal B breast cancers by enhancing cell migration, invasion and reducing endocrine sensibility (Veeraraghavan et al. 2014). However, until now, no clinical studies have been carried out in order to address the importance of these types of ESR1 gene alterations concerning clinical outcome.

Another mechanism that appears to be associated to AIs acquired resistance is the amplification of ESR 1 and CYP19A1 genes; however, their clinical prevalence and relevance remain unclear (Holst et al. 2007, Adelaide et al. 2008, Li et al. 2013, Magnani et al. 2017). Recently, using next-generation sequencing, a rate of around $2 \%$ in both primary and metastatic tumours was described by different studies (Cancer Genome Atlas Network 2012, Jeselsohn et al. 2015), and it was suggested that this amplification may not play an important role in resistance development (Jeselsohn et al. 2015). In relation to CYP19A1, very rare prevalence rates have been reported $(0.006 \%)$ in earlystage disease (Cancer Genome Atlas Network 2012), while in metastatic tumours, higher amplification rates (16-32\%) were described in patients that received AIs (Magnani et al. 2017).

\section{Aberrant growth factor receptors expression/activation}

Over the last decade, several studies have described deregulated pathways and adaptive changes due to prolonged estrogen deprivation and ER signalling disruption. The deregulated activation of GFRs (Stephen et al. 2001, Turner et al. 2010, Fox et al. 2011, Mehta \& Tripathy 2014, Andre \& Cortes 2015, Flageng et al. 2017) and their downstream signalling components, including MAPKs (Jeng et al. 2000, Martin et al. 2003) and PI3K pathways (Miller et al. 2010, Fox et al. 2013), have been associated with AIs acquired resistance. In fact, the crosstalk between ER and GFRs allows breast cancer cells to bypass estrogen deprivation by modulating ER expression and activity. Moreover, it was demonstrated that HER2 aberrant activation is possibly due to increased expression of neuregulin-1 (NRG1) (Flageng et al. 2017), a HER ligand. The increase in HER2 activation leads to a ligand-independent activation of ER through MAPK phosphorylation on S118, inducing acquired resistance to AIs (Kato et al. 1995, Mehta \& Tripathy 2014). Recently, the importance of ER in driving the growth of AIs-resistant cells through a ligand-independent ER activation was strengthened (Hole et al. 2015a). This resistance is surpassed by ER downregulation through the addition of the SERD fulvestrant (Bartsch et al. 2007, Hole et al. 2015a). Furthermore, a sustained overexpression of HER2 may lead to the loss of ER expression as a mechanism of resistance, bypassing, in these cases, the beneficial effects of fulvestrant and rendering these cells ligand and ER independent (Massarweh \& Schiff 2007). Similar observations were reported regarding the PI3K/AKT pathway (Sikora et al. 2012), with the AKT downstream effector, p70S6K, being responsible for the ER phosphorylation on S167 (Campbell et al. 2001), and for the loss of ER expression (Creighton et al. 2010). In the latter case, AKT blocks the translocation of the transcription factor forkhead box O3A (FOXO3A) to the nucleus and its binding to the ESR1 promoter. Therefore, inhibition of PI3K induces ER expression through FOXO3A (Brunet et al. 1999, Guo \& Sonenshein 2004). Nevertheless, the contrary is also true, since ER has the ability to bind to the regulatory subunit of PI3K, p85, activating the catalytic subunit, p110 (Simoncini et al. 2000). Mutations in the PI3K gene, PIK3CA (Perez-Tenorio et al. 2007, Stemke-Hale et al. 2008, Ellis et al. 2010), or the loss of phosphatase and tensin homolog (PTEN) expression (Perez-Tenorio et al. 2007, Saal et al. 2007) may activate this pathway independently of GFRs.

Several approaches to prevent or delay acquired resistance, through the inhibition of GFRs, which will be discussed later, have been tested in clinical studies. Nevertheless, more information is needed in order to fully understand the therapeutic importance of targeting the GFRs and downstream effectors in metastatic $\mathrm{ER}^{+}$patients with acquired resistance to AIs.

\section{ER hypersensitivity to low estrogen levels}

Several studies have shown that tumours retaining ER expression can escape the limitations of estrogen deprivation, by increasing their hypersensitivity to residual levels of estrogens. Curiously, in these cases, high doses of estrogen are known to inhibit cell growth and induce apoptosis of resistant cells (Masamura et al. 
1995, Ellis et al. 2009, Zucchini et al. 2015), though, recent studies have suggested that the exact mechanism of ER hypersensitivity may differ according to estrogen levels (Sikora et al. 2012). Santen et al. reported that the ER-mediated transcription of genes is different when the ER is hypersensitive (Santen et al. 2005). The main mechanisms, in this case, are the interactions with the GFR signalling pathways, together with non-genomic actions near or at the cell membrane (Santen et al. 2009). This suggested that interactions with GFR signalling pathways do not simply restore the normal ER function, but by increasing ER phosphorylation, alter and enhance ER-mediated transcription of genes. This theory is supported by the finding that elevated AKT levels can alter the genome-wide binding pattern of ER compared to the one seen in wild-type cells (Bhat-Nakshatri et al. 2008). Thus, these findings indicate that disrupting GFR signalling may be a more realistic approach in preventing ER hypersensitivity than to abrogate estrogen action. GFR signalling blockade in AI-resistant breast cancer is already under investigation and will be discussed later.

\section{Androgens and androgen receptor}

AR is a steroid receptor, similar to ER, involved in several physiological processes. Approximately, $85-95 \%$ of the $\mathrm{ER}^{+}$breast cancers, and $77 \%$ of invasive breast cancers, express AR (Collins et al. 2011, Proverbs-Singh et al. 2015). Curiously, it is known that AR can be recruited to ERE, and that the ER can also be recruited to androgen-responsive elements (ARE), which proves the structural similarities of these receptors, especially in the DBD (Peters et al. 2009, Rechoum et al. 2014).

In AIs-sensitive breast cancer cells, the ER and AR have opposite effects. ER promotes cell growth while AR induces cell death. In these cases, AR overexpression is linked with improved disease-free survival (DFS), when compared with AR-negative cancers. Moreover, the absence of AR expression predicts an earlier treatment failure with AIs (Macedo et al. 2006, Elebro et al. 2015).

In AIs-resistant breast cancer cells, several studies suggested a different role for androgens and AR in cell fate (Macedo et al. 2006, Chia et al. 2015). One of the proposed mechanisms for AIs-acquired resistance involves AR overexpression, as a response to decreased ER activity (Fujii et al. 2014, Ali et al. 2015). To enhance ER transcriptional activity, a cooperation between AR and ER, via PI3K pathway, have been described (Rechoum et al. 2014). Another proposed mechanism involves $5 \alpha$-androstane-

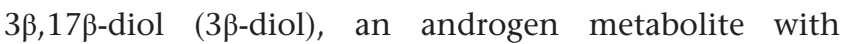

androgenic and estrogenic activities, that induces ER activation (Hanamura et al. 2013). Curiously, despite the pro-survival effects in the resistance onset, $3 \beta$-diol inhibits the growth of MCF-7 cells due to its agonistic effects on ER $\beta$ (Lattrich et al. 2013). The production of this androgen metabolite causes a decrease in AR signalling, since androgens are converted into $3 \beta$-diol, by the estrogen

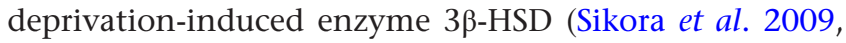
Hanamura et al. 2013).

Based on these findings, several clinical trials are ongoing in order to assess the viability of modulating AR, both positively and negatively, in $\mathrm{ER}^{+} / \mathrm{AR}^{+}$breast cancer cases. The efficacy and safety of a selective androgen receptor modulator, enobosarm, for the treatment of $\mathrm{ER}^{+} / \mathrm{AR}^{+}$patients (NCT02463032) is being assessed, and the evaluation of the effects of enzalutamide, an AR antagonist, alone or in combination with exemestane is ongoing in a phase II clinical trial (NCT02007512). Recently, the latter clinical trial was supported by a phase $\mathrm{I} / \mathrm{Ib}$ study with the combination of enzalutamide with anastrozole, exemestane or fulvestrant (Schwartzberg et al. 2017). Moreover, the combination of the AR antagonist, bicalutamide and an aromatase inhibitor is also being studied in a clinical trial (NCT02910050).

Thus, although $\mathrm{AR}$ is considered as a favourable prognostic marker, the exact role and importance of targeting AR in AIs-acquired resistance is not well defined, and further studies need to be performed. Nevertheless, the recent discovery of the importance of AR in breast cancer and its dual role in AR-sensitive and resistant cells, praise its significance as an attractive therapeutic target.

\section{Cell cycle related mechanisms}

Aberrant expression/activation of cell cycle regulators has also been associated with AIs-acquired resistance. Ormandy et al. had previously shown that the cyclin D1 encoding gene, CCND1, is commonly amplified in breast cancer (Ormandy et al. 2003). This overexpression may inhibit CDK interacting protein/kinase inhibitory protein (CIP/KIP) molecules that are pivotal for cell cycle regulation (Hui et al. 2002, Chu et al. 2008). Several survival pathways, such as MAPK, NF-kB or ER $\alpha$, promote the expression of cyclin D1 (Altucci et al. 1996), which can directly activate $\mathrm{ER} \alpha$ in a cyclin-CDK complexindependent way (Zwijsen et al. 1997). This cyclin is responsible for the progression of G1-to-S phases, by forming a complex with cyclin-dependent kinase $4 / 6$ (CDK4/6), inactivating the retinoblastoma protein and inducing the synthesis of cyclin E. The joint action of 
cyclin D1-CDK4/6 and cyclin E-CDK2 contributes to the progression of cell cycle.

Following the results of the PALOMA-1/TRIO-18 (NCT00721409) and MONALEESA-2 (NCT01958021) clinical trials, the combinations of two CDK 4/6 inhibitors, palbociclib and ribociclib, with letrozole were approved by FDA as first-line treatment in $\mathrm{ER}^{+}$postmenopausal women. These combinations demonstrated an increase in progression-free survival when compared to letrozole alone (Finn et al. 2014, 2015, Beaver et al. 2015, Hortobagyi et al. 2016). The combination of palbociclib with fulvestrant was also approved since according to PALOMA-3 phase 3 randomised controlled clinical trial (NCT01942135), an improvement on progression-free survival was observed when compared with fulvestrant alone (Cristofanilli et al. 2016). Furthermore, the CDK $4 / 6$ inhibitors, abemaciclib and ribociclib, are also being studied in combination with anti-estrogens (Hortobagyi et al. 2016). In addition, an overexpression of Aurora kinases in models of resistance to third-generation AIs was recently reported (Hole et al. 2015b). Aurora kinases are Ser/Thr kinases involved in cell proliferation through the control of chromatid segregation. These results support the idea that targeting cell cycle regulators, in particular CDK4/6, is a promising therapeutic option. Indeed, modulators of the cell cycle have gained reputation in the last years as attractive strategies to overcome resistance.

\section{Apoptosis, autophagy and endoplasmic reticulum stress}

In addition to cell cycle regulators, apoptosis resistance and/or pro-survival autophagy are also described mechanisms associated to AIs-acquired resistance. In fact, an upregulation of the anti-apoptotic molecules, Bcl-2 and Bcl-xL, and a downregulation of the proapoptotic molecules, Bad and Bik, blocked anti-estrogen therapy-induced apoptosis (Musgrove \& Sutherland 2009, Dalby et al. 2010, Giuliano et al. 2011). Moreover, the downregulation of programmed cell death 4 (PDCD4), an apoptosis-induced tumour suppressor that inhibits protein translation, is associated with poor prognosis in AIs-resistant cells (Chen et al. 2015b).

Autophagy has also been associated with endocrine resistance to anti-estrogen therapies (Cook et al. 2011, Amaral et al. 2012, 2013, Cook \& Clarke 2014). Autophagy is regulated by the anti-apoptotic protein Bcl-2 and by PI3K pathway, through mammalian target of rapamycin (mTOR) activation, which inhibits autophagy initiation (He \& Klionsky 2009). A recent in vitro study suggested that one of the reasons for the insensitivity to everolimus, an mTORC1 inhibitor, is the autophagic activation. In this study, autophagic inhibition by chloroquine restored sensitivity to everolimus in AIs-resistant breast cancer cells derived from MCF7 cells, suggesting a protective role of this cellular process in AIs-acquired resistance (Lui et al. 2016).

c-MYC gene expression has also been shown to be upregulated in AIs-resistant cells. This upregulation was due to a crosstalk between HER2 and ER (Miller et al. 2011, Chen et al. 2015a) and was associated with everolimus resistance in AIs-resistant breast cancer cells (Bihani et al. 2015). As c-MYC regulates the autophagic process through changes in Bcl-2 phosphorylation in cancer cells (Toh et al. 2013), the study of c-MYC involvement in resistance to everolimus demonstrated that autophagy was associated with everolimus insensitivity to AIs-resistant breast cancer, as discussed earlier (Lui et al. 2016).

The unfolded protein response (UPR) has also been linked to the regulation of autophagy-apoptosis switch. The UPR regulator, glucose-regulated protein (GRP78), is overexpressed in $\mathrm{ER}^{+}$acquired resistant cells and has been shown to balance the pro-survival autophagy and apoptosis, conferring resistance to the hormonal therapy in vitro and in vivo (Cook et al. 2012, 2014). The GRP78 stimulates autophagy through mTOR inhibition, and its knockdown re-sensitised breast cancer cells through apoptosis induction (Cook et al. 2012).

Recently, the relevance of endoplasmic reticulum homeostasis in AIs-acquired resistance was demonstrated by a study showing that inhibition of the serum/ glucocorticoid-regulated kinase 3 (SGK3) induced a reduction in AIs-resistant cells survival. SGK3 is upregulated in AIs-resistant cells, maintaining the endoplasmic reticulum calcium levels, by preserving endoplasmic reticulum calcium ATPase 2b (SERCA2b) activity, involved in endoplasmic reticulum homeostasis (Wang et al. 2017).

\section{Other mechanisms}

The role of miRNAs (miR) in endocrine resistance is currently being explored (Muluhngwi \& Klinge 2015). Vilquin et al. reported a deregulation of miR-125b, miR-205 and miR-424 in acquired letrozoleand Anastrozole-resistant cell models, when compared to a hormone-sensitive breast cancer cell line that overexpresses aromatase (MCF-7aro). Expression levels of miR-125b and miR-205 were upregulated, whereas miR-424 was downregulated. This deregulation was sufficient to confer resistance to letrozole and anastrozole 
by the activation of the PI3K/AKT pathway, in MCF-7aro cells transfected with miR-125b, miR-205 or treated with inhibitors of miR-424 (Vilquin et al. 2015). Other studies also correlated miR-155 and miR-128a with a poor response to anastrozole and letrozole, respectively (Masri et al. 2010a, Bacci et al. 2016).

\section{Molecular alterations in resistance to third-generation Als}

The third-generation AIs are very effective, potent and specific; but tumours still relapse in many patients because of acquired resistance. The lack of cross-resistance among AIs however suggests different resistance mechanisms (Lonning 2008, 2009). In this section, a global overview of molecular alterations described for each third-generation AIs resistance model will be accomplished (Table 1).

\section{Letrozole resistance}

Several mechanisms that involve MAPK and PI3K pathways and cell cycle regulators are linked to letrozole acquired resistance. Letrozole-resistant cells exhibit a dependency on the MAPKs pathways, mainly through HER2 and EGFR overexpression (Tilghman et al. 2013), which highlights the role of GFRs on the ligand-independent activation of ER (Fig. 1). Co-targeting HER2, via trastuzumab, and ER signalling, in long-term letrozole-treated tumour (LTLT-Ca) cells, a resistant cell model, restored letrozole sensitivity, inducing tumour regression as a consequence of a re-expression of ER (Jelovac et al. 2005, Sabnis et al. 2009, 2010, Sabnis \& Brodie 2010). Nevertheless, recent data also described that letrozole-resistant cells present a higher expression/activation of the PI3K/AKT/mTOR pathway. In a reported phase I trial (NCT01248494), the inhibitor buparlisib (BKM120) showed to be safe and to have anti-tumour efficacy in combination with letrozole (Mayer et al. 2014). Different PI3K inhibitors, such as pilaralisib and voxtalisib, are currently being tested in phase I/II studies (Blackwell et al. 2015). Moreover, in letrozole-resistant cells, taselisib, also a PI3K inhibitor, demonstrated anti-tumour efficacy in combination with letrozole (Hoeflich et al. 2016).

Recent studies have also described an association with cell cycle regulation and letrozole resistance. FDA recently approved as first-line treatment in $\mathrm{ER}^{+}$postmenopausal women the inhibition of CDK $4 / 6$ with palbociclib in combination with letrozole. This approach showed high efficacy, as previously described by the PALOMA-1/TRIO-18 (NCT00721409) clinical trial, and the ability to prevent letrozole resistance (Finn et al. 2014, 2015, Beaver et al.

Table 1 Summary of the main mechanisms of acquired resistance to third-generation Als.

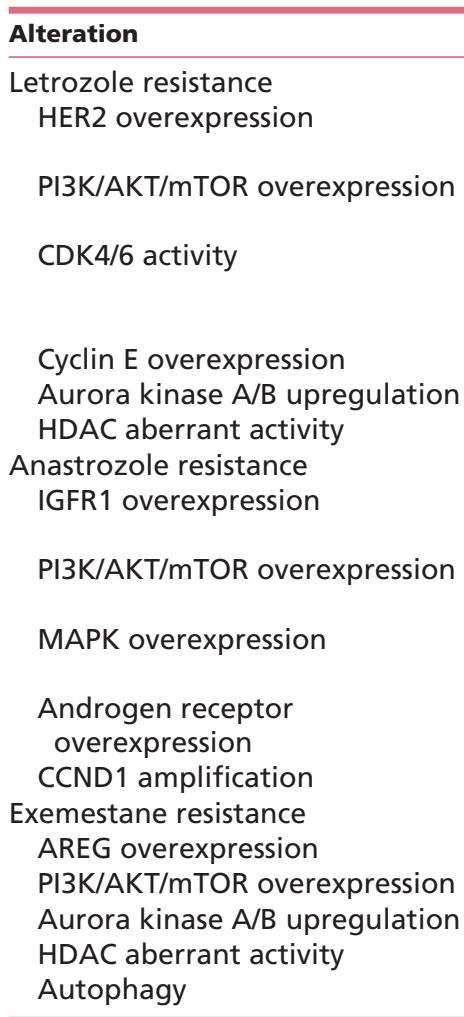

http://erc.endocrinology-journals.org https://doi.org/10.1530/ERC-17-0425
Mechanism of resistance

Decrease expression and ligand-independent activation of ER

Decrease expression and ligand-independent activation of ER

Promotion of cell cycle progression

Promotion of cell cycle progression

Promotion of cell cycle progression

HER2 modulation

Decrease expression and ligand-independent activation of ER

Decrease expression and ligand-independent activation of ER

Decrease expression and ligand-independent activation of ER

Increase IGF1R and PI3K/AKT/mTOR signalling

Promotion of cell cycle progression

Increase MAPK pathway activity

Decrease expression of ER

Promotion of cell cycle progression

NF- $\kappa \mathrm{B}$ expression

Pro-survival cellular mechanism
References

Jelovac et al. (2005), Sabnis et al. (2009),

Sabnis \& Brodie (2010)

Cavazzoni et al. (2012), Mayer et al. (2014), Hoeflich et al. (2016)

Finn et al. (2014, 2015), Beaver et al. (2015), Hortobagyi et al. (2016), (American

Association for Cancer Research 2017)

Akli et al. (2010)

Hole et al. (2015b)

Sabnis et al. (2013a), Schech et al. (2015)

Macedo et al. (2008), Rechoum et al. (2014)

Vilquin et al. (2013), Schmid et al. (2016)

Sabnis et al. (2013b)

Rechoum et al. (2014)

Lundgren et al. (2012)

Wang et al. (2008)

Baselga et al. (2012), Steger et al. (2017)

Hole et al. (2015b)

Kubo et al. (2013), Yardley et al. (2013)

Amaral et al. (2012, 2013)

\section{(C) 2018 Society for Endocrinology Published by Bioscientifica Ltd. Printed in Great Britain}




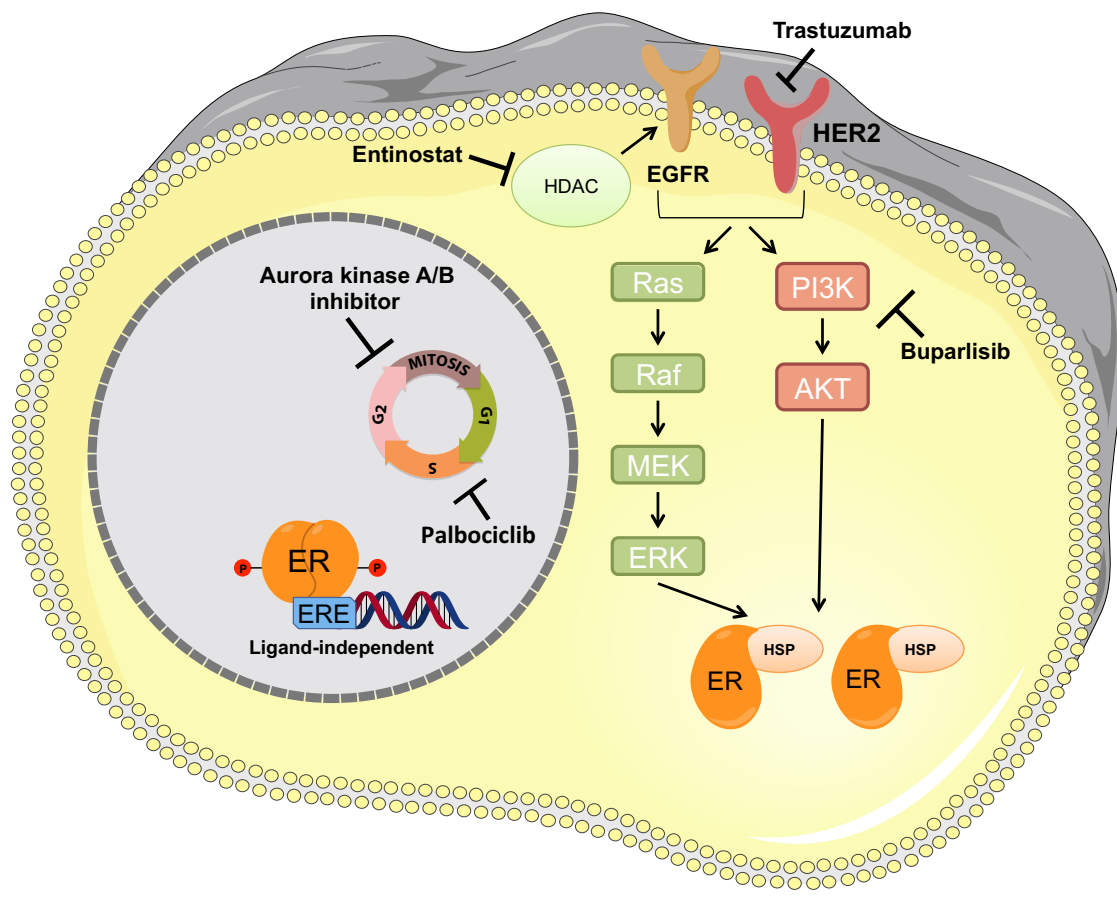

Figure 1

Letrozole-acquired resistance mechanisms. Letrozole presents several resistance mechanisms that are estrogen-independent and related to the overexpression of survival/proliferation pathways, such as PI3K/AKT and MAPK/ERK. Some strategies are being studied, like the use of HDAC inhibitors, such as entinostat, HER2 blockade by Trastuzumab, PI3K inhibition by buparlisib or cell cycle regulation by Aurora kinase $A / B$ inhibitors or by palbociclib. AKT, serine/threonine specific-protein kinase family; EGFR, epidermal growth factor receptor; ER, estrogen receptor; ERE, estrogen responsive element; ERK, extracellular signal-regulated kinases; HDAC, histone deacetylase; HER2, human epidermal growth factor receptor 2; HSP, heat shock protein; MAPK, mitogen-activated protein kinase; PI3K, phosphoinositide 3-kinase. A full colour version of this figure is available at https://doi. org/10.1530/ERC-17-0425.

2015). Moreover, the MONALEESA-2 (NCT01958021) clinical trial demonstrated that, in postmenopausal women with ER+/HER2- advanced breast cancer without prior therapy, the combination of letrozole with a different CDK 4/6 inhibitor, ribociclib, extended progressionfree survival when compared to letrozole alone. FDA also approved this combination (Hortobagyi et al. 2016, American Association for Cancer Research 2017).

An upregulation of Aurora kinase A and B also seems to be involved in letrozole acquired resistance. Their inhibition resulted in tumour growth suppression, indicating that these kinases might be new potential therapeutic targets (Hole et al. 2015b). Moreover, studies involving the histone deacetylase (HDAC) inhibitor, entinostat, suggested a beneficial effect, through HER2 modulation, on LTLT-Ca cells and on Letrozole-resistant MCF-7Ca xenografts (Sabnis et al. 2013a, Schech et al. 2015).

\section{Anastrozole resistance}

Different mechanisms were described to be associated with anastrozole resistance, and most of these seem to share the same growth factor receptor aberration. Anastrozole-resistant cells do not exhibit an upregulation in HER2 like in letrozole resistance (Fig. 2). Instead, they present an increase in IGFR1 and a reduction in ER expression and aromatase activity, with an upregulation of the PI3K/AKT pathway (Macedo et al. 2008, Rechoum et al. 2014). In fact, a study conducted by Rechoum et al. showed that overexpression of AR and a cooperation between $\mathrm{AR}$ and $\mathrm{ER}$ led to anastrozole resistance of MCF-7 cells that overexpress aromatase and AR, through the activation of IGF1R and PI3K/AKT pathways. Consistently, the use of an IGF1R inhibitor, AG1024, or a dual kinase AKT inhibitor, Akti $1 / 2$, restored sensitivity to anastrozole (Rechoum et al. 2014). Similar results were found using the AKT/mTOR inhibitor MK-2206, on anastrozole-resistant cells derived from aromatase-overexpressing MCF-7 cells (Vilquin et al. 2013), and the PI3K inhibitor pictilisib on a phase II randomised trial (Schmid et al. 2016). Therefore, it can be concluded that targeting the PI3K/AKT/mTOR pathway in anastrozole resistance is of major importance. This was strengthened by the use of a MAPK inhibitor, selumetinib, which caused a downregulation of activated MAPK and phosphorylated mTOR, reverting anastrozole resistance (Sabnis et al. 2013b).

Moreover, in a TransATAC study, it was observed that amplifications of the CCND1, a gene that encodes cyclin D1, were associated with an increased risk of tumour recurrence in response to anastrozole (Lundgren et al. 2012). In fact, the biological effects of the combination of a CDK 4/6 inhibitor, abemaciclib, plus anastrozole vs anastrozole or abemaciclib alone, are being evaluated by the ongoing neoMONARCH clinical trial (NCT02441946).

\section{Exemestane resistance}

Exemestane, the only steroidal AI of the third-generation group, has a different resistance mechanism when http://erc.endocrinology-journals.org https://doi.org/10.1530/ERC-17-0425
C 2018 Society for Endocrinology Published by Bioscientifica Ltd. Printed in Great Britain 


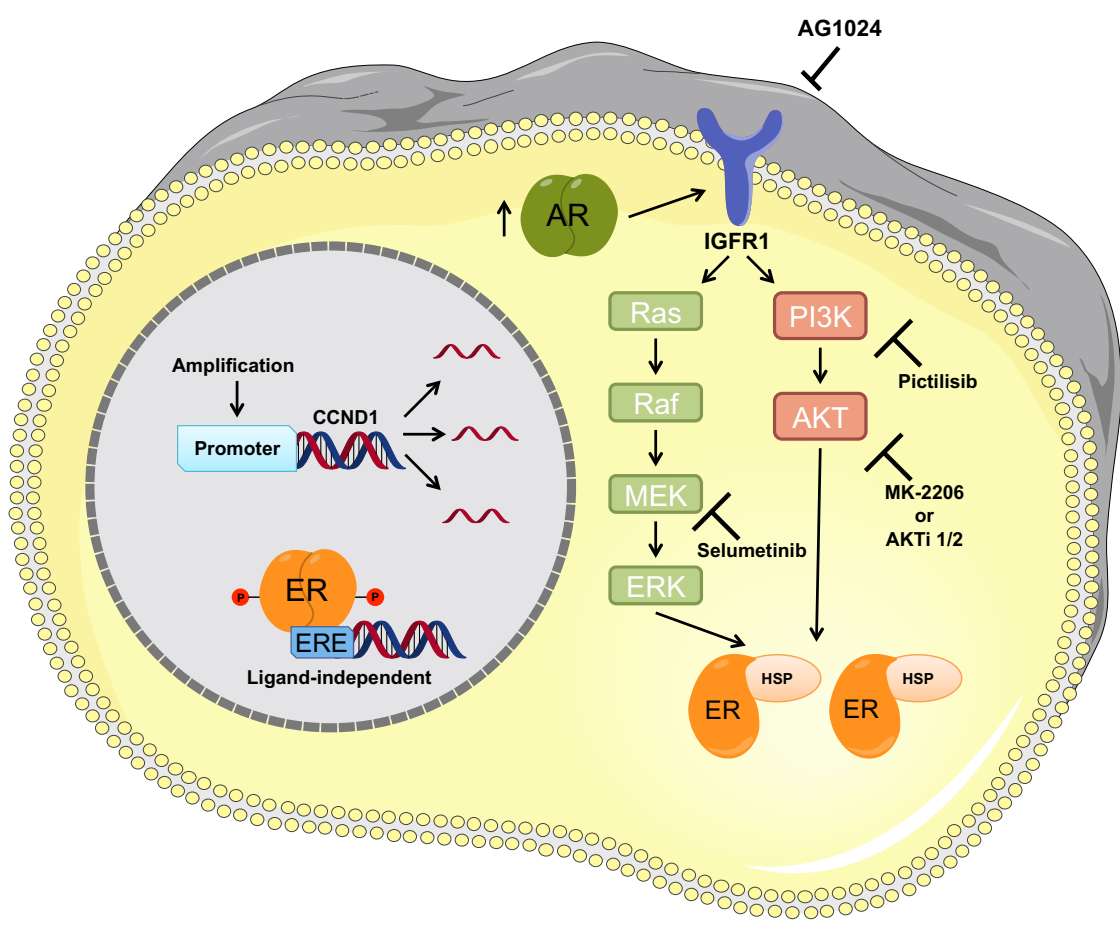

Figure 2

Anastrozole-acquired resistance mechanisms. Anastrozole presents several resistance mechanisms that are estrogen-independent and related to the overexpression of survival/ proliferation pathways, such as PI3K/AKT and MAPK/ERK and to the amplification of a cell cycle regulator gene, CCND1. Some strategies are being studied, including IGFR1 blockade by AG1024, PI3K inhibition by pictilisib, AKT inhibition by MK-2206 or Akti $1 / 2$ and MEK inhibition by selumetinib. AKT, serine/threonine specific-protein kinase family; $A R$, androgen receptor; ER, estrogen receptor; ERE, estrogen responsive element; ERK, extracellular signalregulated kinases; HSP, heat shock protein; IGFR, insulin-like growth factor receptor; MAPK mitogen-activated protein kinase; PI3K, phosphoinositide 3-kinase. A full colour version of this figure is available at https://doi. org/10.1530/ERC-17-0425.

compared to the two non-steroidal AIs (Fig. 3). Contrary to non-steroidal AI-resistant cells, Exemestane-resistant cancer cells continue to present a hormone-dependent behaviour (Masri et al. 2010b, Chen 2011). In the last years, different mechanisms have been associated with exemestane acquired resistance, with some of them being common to non-steroidal AIs while others are apparently specific for this steroidal AI.
It has been suggested that exemestane resistance results from its weak estrogen-like activity, through the involvement of amphiregulin (AREG) expression (Wang et al. 2008). Exemestane may induce AREG upregulation in a similar way to estrogens (Frasor et al. 2004), through an ER-dependent manner (Wang et al. 2008). AREG is an epidermal-like growth factor that binds to and activates EGFR, leading to tumour proliferation through the MAPK

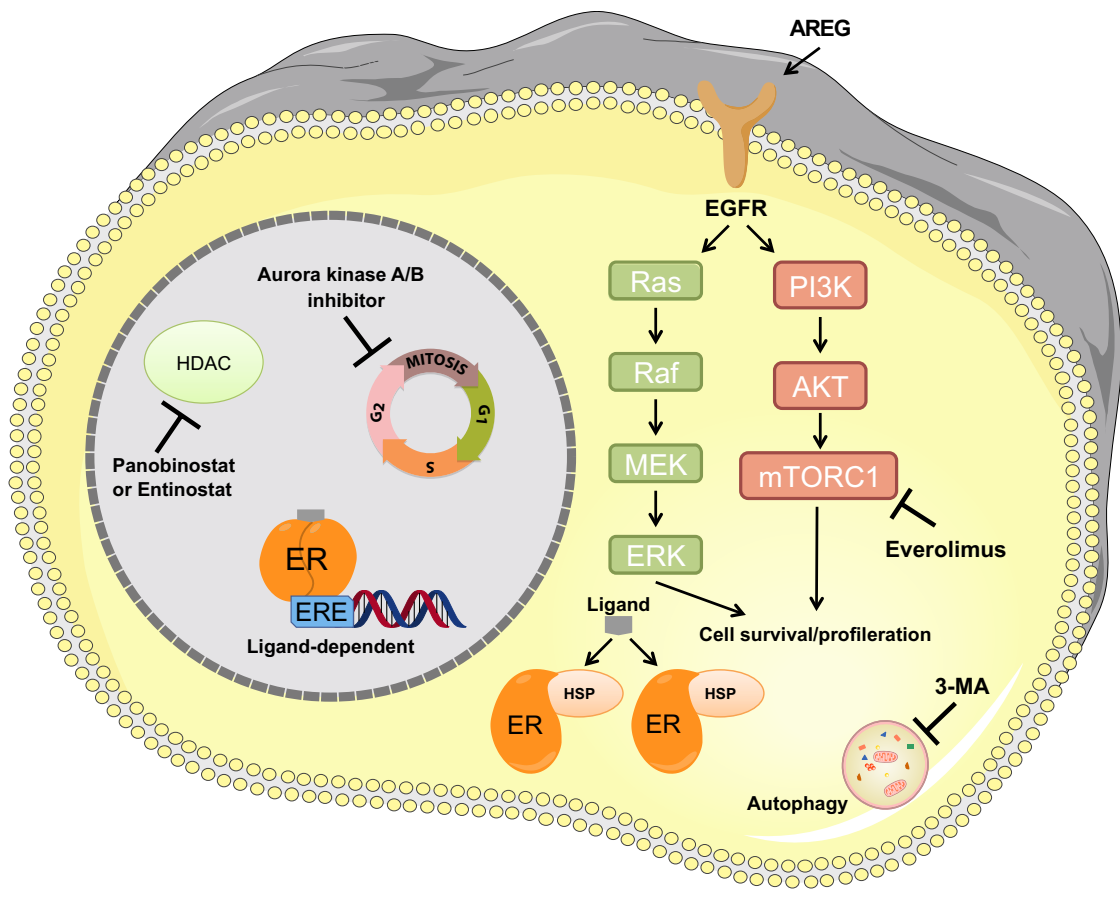

Figure 3

Exemestane-acquired resistance mechanisms. Exemestane presents several resistance mechanisms that are estrogen-dependent and related to the overexpression of survival/ proliferation pathways, such as PI3K/AKT and MAPK/ERK. Some strategies are being studied, like HDAC inhibition by panobinostat or entinostat, mTORC1 inhibition by everolimus, autophagic inhibition by 3-MA and cell cycle regulation by Aurora kinase A/B inhibition. 3-MA, 3-methyladenine; AKT, serine/threonine specific-protein kinase family; AREG, amphiregulin; EGFR, epidermal growth factor receptor; ER, estrogen receptor; ERE, estrogen responsive element; ERK, extracellular signalregulated kinases; HDAC, histone deacetylase; HSP, heat shock protein; MAPK, mitogenactivated protein kinase; $\mathrm{mTORC1}$, mammalian target of rapamycin complex 1; PI3K phosphoinositide 3-kinase. A full colour version of this figure is available at https://doi. org/10.1530/ERC-17-0425. 
pathway (Wang et al. 2008, Masri et al. 2010b). As expected, AREG or MAPK inhibition suppresses proliferation of exemestane-resistant cancer cell lines.

The inhibition of PI3K/AKT/mTOR pathway, through everolimus, when combined with exemestane, seems to be very effective in $\mathrm{ER}^{+}$patients with advanced disease after non-steroidal AI therapy, as shown by the clinical trials STEPAUT and BOLERO-2 (Baselga et al. 2012, Steger et al. 2017). mTOR inhibition exhibits high antiproliferative effects, through reduced translation of cyclin D1, inducing cell cycle arrest at the G1/S phase (Dowling et al. 2010, Lui et al. 2016). However, some details need to be taken into account in relation to the positive outcomes of the BOLERO-2 trial. In this clinical trial, there is a lack of statistically significant survival benefit, despite the improvement in progression-free survival (Piccart et al. 2014). One of the reasons may reside in the complex negative feedback loop between mammalian target of rapamycin complex 1 (mTORC1) and insulin-like growth factor-1 (IGF-1), as inhibition of mTORC1 leads, paradoxically, to the activation of AKT (Wan et al. 2007, LoRusso 2013). Nevertheless, this therapy was approved by FDA (Cook et al. 2012), suggesting that targeting PI3K pathway can have clinical benefits.

Hanamura et al. have demonstrated that, besides inducing estrogen deprivation, exemestane therapy increases intratumoural androgen levels (Hanamura et al. 2013). In fact, ongoing clinical trials are studying the combination of the AR antagonist, enzalutamide, with exemestane (NCT02007512). Nevertheless, in postmenopausal patients pre-treated with non-steroidal AIs (NCT01381874), the inhibition of androgen biosynthesis, by abiraterone acetate (AA) plus prednisone, in combination with exemestane, did not improve progression-free survival when compared to exemestane treatment (O'Shaughnessy et al. 2016).

Another described mechanism associated with exemestane resistance, is the upregulation of the cell cycle regulators, Aurora kinase A and B, in resistant cells derived from MCF-7 cells (Hole et al. 2015b). Moreover, a recent phase III study is currently evaluating the efficacy of palbociclib, in combination with Exemestane or fulvestrant, vs capecitabine (NCT02028507) (Martín et al. 2017).

Genetic and epigenetic alterations are also known to play a role in exemestane resistance. In fact, HDAC inhibitors also seem to reverse exemestane resistance in resistant cells derived from MCF-7-aro cells (Kubo et al. 2013). In this study, the HDAC inhibitor, panobinostat, inhibited exemestane-resistant cancer cell proliferation, through cell cycle arrest and apoptosis. Similarly, the use of the HDAC inhibitor, entinostat, has also shown promising results in a randomised phase II, double-blind, placebo-controlled study (NCT00676663) (Yardley et al. 2013). For this reason, this combination is now being studied in a phase III clinical trial (NCT02115282).

Finally, autophagy is also another potential mechanism associated with exemestane resistance, since it appears to act as a pro-survival mechanism. Our group described that the combination of the autophagic inhibitor, 3-methyladenine (3-MA), with exemestane re-sensitised resistant breast cancer cells (Amaral et al. 2012, 2013). A recent analysis, in $\mathrm{ER}^{+}$carcinoma cells of patients following adjuvant exemestane treatment, demonstrated an increase in the immunoreactivity of autophagic markers, LC3 and beclin-1, and a correlation between beclin-1 levels in pre-treated stromal cells and poor clinical response to endocrine therapy (Ueno et al. 2016). Thus, this highlights the autophagic process as an important player to overcome resistance, in order to achieve therapeutic success.

\section{Conclusions}

The third-generation AIs are very effective, potent and specific; however, the development of AIs acquired resistance may lead to the relapse of $\mathrm{ER}^{+}$breast tumours, this being the major concern in breast cancer therapy. The lack of cross-resistance among the different AIs proposes the existence of different resistance mechanisms. Besides the evidence provided by basic and translational research, the underlying mechanisms are not fully elucidated since some are based on data provided by various cellular models, producing confusing and complex findings. Nevertheless, some of them appear to be common to all AIs, while others seem to be AI specific. Targeting these aberrant pathways and molecules, according to the results obtained in in vitro studies and in clinical trials, suggests a beneficial effect, though no expansion on overall survival is observed in clinical setting. Overall, this shows the complexity of the mechanisms involved in breast cancer resistance, which emphasises the need to elucidate the underlying mechanisms in order to find new promising targets to improve AIs breast cancer therapy.

\section{Declaration of interest}

The authors declare that there is no conflict of interest that could be perceived as prejudicing the impartiality of this review.

\section{Funding}

This work was supported by the Post-Doc (SFRH/BPD/98304/2013) and $\mathrm{PhD}(\mathrm{BD} / 128333 / 2017)$ grants and by the project (UID/MULTI/04378/2013 - POCI/01/0145/FEDER/007728) from FCT/MEC through national funds and co-financed by FEDER, under the Partnership Agreement PT2020. 


\section{Author contribution statement}

T V A and C A wrote the paper. G C d S, N T and C A revised the manuscript. T V A, G C d S, C M P R, N T and C A read and approved the manuscript for publication.

\section{Acknowledgements}

The authors are grateful to Fundação Para a Ciência e Tecnologia (FCT) for Cristina Amaral Post-Doc grant (SFRH/BPD/98304/2013) and for Tiago Augusto PhD grant (BD/128333/2017) funded in part by FCT PhD Programme in Medicines and Pharmaceutical Innovation (i3DU). They also thank FCT for the financial support (UID/MULTI/04378/2013 - POCI/01/0145/ FEDER/007728) from FCT/MEC through national funds and co-financed by FEDER, under the Partnership Agreement PT2020. The authors also thank Joana Macedo for helping with the graphic design.

\section{References}

Aapro MS 2004 Long-term implications of bone loss in breast cancer. Breast 13 (Supplement 1) S29-S37. (https://doi.org/10.1016/j. breast.2004.09.005)

Adelaide J, Finetti P, Charafe-Jauffret E, Wicinski J, Jacquemier J, Sotiriou C, Bertucci F, Birnbaum D \& Chaffanet M 2008 Absence of ESR1 amplification in a series of breast cancers. International Journal of Cancer 123 2970-2972. (https://doi.org/10.1002/ijc.23786)

Akli S, Bui T, Wingate H, Biernacka A, Moulder S, Tucker SL, Hunt KK \& Keyomarsi K 2010 Low-molecular-weight cyclin E can bypass letrozole-induced G1 arrest in human breast cancer cells and tumors. Clinical Cancer Research 16 1179-1190. (https://doi. org/10.1158/1078-0432.CCR-09-1787)

Ali A, Creevey L, Hao Y, McCartan D, O'Gaora P, Hill A, Young L \& McIlroy M 2015 Prosaposin activates the androgen receptor and potentiates resistance to endocrine treatment in breast cancer. Breast Cancer Research 17 123. (https://doi.org/10.1186/s13058-015-0636-6)

Altucci L, Addeo R, Cicatiello L, Dauvois S, Parker MG, Truss M, Beato M, Sica V, Bresciani F \& Weisz A 1996 17beta-Estradiol induces cyclin D1 gene transcription, p36D1-p34cdk4 complex activation and $\mathrm{p} 105 \mathrm{Rb}$ phosphorylation during mitogenic stimulation of $\mathrm{G}(1)$ arrested human breast cancer cells. Oncogene 12 2315-2324.

Amaral C, Borges M, Melo S, da Silva ET, Correia-da-Silva G \& Teixeira N 2012 Apoptosis and autophagy in breast cancer cells following exemestane treatment. PLoS ONE 7 e42398. (https://doi.org/10.1371/ journal.pone.0042398)

Amaral C, Varela C, Azevedo M, da Silva ET, Roleira FM, Chen S, Correia-da-Silva G \& Teixeira N 2013 Effects of steroidal aromatase inhibitors on sensitive and resistant breast cancer cells: aromatase inhibition and autophagy. Journal of Steroid Biochemistry and Molecular Biology 135 51-59. (https://doi.org/10.1016/j. jsbmb.2012.12.017)

American Association for Cancer Research 2017 Ribociclib approved for advanced breast cancer. Cancer Discovery 7 OF3. (https://doi. org/10.1158/2159-8290.CD-NB2017-043)

Amir E, Seruga B, Niraula S, Carlsson L \& Ocana A 2011 Toxicity of adjuvant endocrine therapy in postmenopausal breast cancer patients: a systematic review and meta-analysis. Journal of the National Cancer Institute 103 1299-1309. (https://doi.org/10.1093/ jnci/djr242)

Andre F \& Cortes J 2015 Rationale for targeting fibroblast growth factor receptor signaling in breast cancer. Breast Cancer Research and Treatment 150 1-8. (https://doi.org/10.1007/s10549-015-3301-y)

Angus L, Beije N, Jager A, Martens JW \& Sleijfer S 2017 ESR1 mutations: moving towards guiding treatment decision-making in metastatic breast cancer patients. Cancer Treatment Reviews 52 33-40. (https:// doi.org/10.1016/j.ctrv.2016.11.001)

Bacci M, Giannoni E, Fearns A, Ribas R, Gao Q, Taddei ML, Pintus G, Dowsett M, Isacke CM, Martin LA, et al. 2016 miR-155 drives metabolic reprogramming of er+ breast cancer cells following longterm estrogen deprivation and predicts clinical response to aromatase inhibitors. Cancer Research 76 1615-1626. (https://doi. org/10.1158/0008-5472.CAN-15-2038)

Bardia A, Kabos P, Elledge R, Wang D, Shen J, Garner F, O'Neill A \& Kaklamani VG 2017 Evaluation of RAD1901, a novel investigational, selective estrogen receptor degrader (SERD), for the treatment of ER-positive (ER+) advanced breast cancer. Journal of Clinical Oncology 35 (15 Suppl) 1014. (https://doi.org/10.1200/JCO.2017.35.15_ suppl.1014)

Bartsch R, Wenzel C, Altorjai G, Pluschnig U, Mader RM, Gnant M, Jakesz R, Rudas M, Zielinski CC \& Steger GG 2007 Her2 and progesterone receptor status are not predictive of response to fulvestrant treatment. Clinical Cancer Research 13 4435-4439. (https://doi.org/10.1158/1078-0432.CCR-06-3050)

Baselga J, Campone M, Piccart M, Burris HA 3rd, Rugo HS, Sahmoud T, Noguchi S, Gnant M, Pritchard KI, Lebrun F, et al. 2012 Everolimus in postmenopausal hormone-receptor-positive advanced breast cancer. New England Journal of Medicine 366 520-529. (https://doi. org/10.1056/NEJMoa1109653)

Beaver JA, Amiri-Kordestani L, Charlab R, Chen W, Palmby T, Tilley A, Zirkelbach JF, Yu J, Liu Q, Zhao L, et al. 2015 FDA approval: palbociclib for the treatment of postmenopausal patients with estrogen receptor-positive, HER2-negative metastatic breast cancer. Clinical Cancer Research 21 4760-4766. (https://doi. org/10.1158/1078-0432.CCR-15-1185)

Bhat-Nakshatri P, Wang G, Appaiah H, Luktuke N, Carroll JS, Geistlinger TR, Brown M, Badve S, Liu Y \& Nakshatri H 2008 AKT alters genome-wide estrogen receptor alpha binding and impacts estrogen signaling in breast cancer. Molecular and Cellular Biology 28 7487-7503. (https://doi.org/10.1128/МСВ.00799-08)

Bihani T, Ezell SA, Ladd B, Grosskurth SE, Mazzola AM, Pietras M, Reimer C, Zinda M, Fawell S \& D'Cruz CM 2015 Resistance to everolimus driven by epigenetic regulation of MYC in ER+ breast cancers. Oncotarget 6 2407-2420. (https://doi.org/10.18632/ oncotarget.2964)

Blackwell K, Burris H, Gomez P, Lynn Henry N, Isakoff S, Campana F, Gao L, Jiang J, Mace S \& Tolaney SM 2015 Phase I/II dose-escalation study of PI3K inhibitors pilaralisib or voxtalisib in combination with letrozole in patients with hormone-receptor-positive and HER2negative metastatic breast cancer refractory to a non-steroidal aromatase inhibitor. Breast Cancer Research and Treatment 154 287-297. (https://doi.org/10.1007/s10549-015-3615-9)

Bonneterre J, Buzdar A, Nabholtz JM, Robertson JF, Thurlimann B, von Euler M, Sahmoud T, Webster A \& Steinberg M 2001 Anastrozole is superior to tamoxifen as first-line therapy in hormone receptor positive advanced breast carcinoma. Cancer 92 2247-2258. (https:// doi.org/10.1002/1097-0142(20011101)92:9<2247::AIDCNCR1570>3.0.CO;2-Y)

Brodie AM, Schwarzel WC, Shaikh AA \& Brodie HJ 1977 The effect of an aromatase inhibitor, 4-hydroxy-4-androstene-3,17-dione, on estrogen-dependent processes in reproduction and breast cancer Endocrinology 100 1684-1695. (https://doi.org/10.1210/endo-100-61684)

Brufsky AM, Harker WG, Beck JT, Bosserman L, Vogel C, Seidler C, Jin L, Warsi G, Argonza-Aviles E, Hohneker J, et al. 2012 Final 5-year results of Z-FAST trial: adjuvant zoledronic acid maintains bone mass in postmenopausal breast cancer patients receiving letrozole. Cancer 118 1192-1201. (https://doi.org/10.1002/cncr.26313)

Brunet A, Bonni A, Zigmond MJ, Lin MZ, Juo P, Hu LS, Anderson MJ, Arden KC, Blenis J \& Greenberg ME 1999 Akt promotes cell survival
2018 Society for Endocrinology Published by Bioscientifica Ltd. Printed in Great Britain 
by phosphorylating and inhibiting a Forkhead transcription factor. Cell 96 857-868. (https://doi.org/10.1016/S0092-8674(00)80595-4)

Bunone G, Briand PA, Miksicek RJ \& Picard D 1996 Activation of the unliganded estrogen receptor by EGF involves the MAP kinase pathway and direct phosphorylation. EMBO Journal 15 2174-2183

Campbell RA, Bhat-Nakshatri P, Patel NM, Constantinidou D, Ali S \& Nakshatri H 2001 Phosphatidylinositol 3-kinase/AKT-mediated activation of estrogen receptor alpha: a new model for anti-estrogen resistance. Journal of Biological Chemistry 276 9817-9824. (https:// doi.org/10.1074/jbc.M010840200)

Cancer Genome Atlas Network 2012 Comprehensive molecular portraits of human breast tumours. Nature $\mathbf{4 9 0} 61-70$. (https://doi. org/10.1038/nature11412)

Cardoso F, Costa A, Senkus E, Aapro M, Andre F, Barrios CH, Bergh J, Bhattacharyya G, Biganzoli L, Cardoso MJ, et al. 2017 3rd ESO-ESMO international consensus guidelines for Advanced Breast Cancer (ABC 3). Breast 31 244-259. (https://doi.org/10.1016/j.breast.2016.10.001)

Cavazzoni A, Bonelli MA, Fumarola C, La Monica S, Airoud K, Bertoni R, Alfieri RR, Galetti M, Tramonti S, Galvani E, et al. 2012 Overcoming acquired resistance to letrozole by targeting the PI3K/AKT/mTOR pathway in breast cancer cell clones. Cancer Letters 323 77-87. (https://doi.org/10.1016/j.canlet.2012.03.034)

Chan HJ, Petrossian K \& Chen S 2016 Structural and functional characterization of aromatase, estrogen receptor, and their genes in endocrine-responsive and -resistant breast cancer cells. Journal of Steroid Biochemistry and Molecular Biology 161 73-83. (https://doi. $\operatorname{org} / 10.1016 /$ j.jsbmb.2015.07.018)

Chandarlapaty S, Chen D, He W, Sung P, Samoila A, You D, Bhatt T, Patel P, Voi M, Gnant M, et al. 2016 Prevalence of ESR1 mutations in cell-free DNA and outcomes in metastatic breast cancer: a secondary analysis of the BOLERO-2 clinical trial. JAMA Oncology 2 1310-1315. (https://doi.org/10.1001/jamaoncol.2016.1279)

Chaudhri RA, Schwartz N, Elbaradie K, Schwartz Z \& Boyan BD 2014 Role of ERalpha36 in membrane-associated signaling by estrogen. Steroids 81 74-80. (https://doi.org/10.1016/j.steroids.2013.10.020)

Chen S 2011 An 'omics' approach to determine the mechanisms of acquired aromatase inhibitor resistance. OMICS 15 347-352. (https:// doi.org/10.1089/omi.2010.0097)

Chen D, Riedl T, Washbrook E, Pace PE, Coombes RC, Egly JM \& Ali S 2000 Activation of estrogen receptor alpha by S118 phosphorylation involves a ligand-dependent interaction with TFIIH and participation of CDK7. Molecular Cell 6 127-137. (https://doi.org/10.1016/S10972765(05)00004-3)

Chen D, Washbrook E, Sarwar N, Bates GJ, Pace PE, Thirunuvakkarasu V, Taylor J, Epstein RJ, Fuller-Pace FV, Egly JM, et al. 2002

Phosphorylation of human estrogen receptor alpha at serine 118 by two distinct signal transduction pathways revealed by phosphorylation-specific antisera. Oncogene 21 4921-4931. (https:// doi.org/10.1038/sj.onc.1205420)

Chen Z, Wang Y, Warden C \& Chen S 2015a Cross-talk between ER and HER2 regulates C-MYC-mediated glutamine metabolism in aromatase inhibitor resistant breast cancer cells. Journal of Steroid Biochemistry and Molecular Biology 149 118-127. (https://doi.org/10.1016/j. jsbmb.2015.02.004)

Chen Z, Yuan YC, Wang Y, Liu Z, Chan HJ \& Chen S 2015b Downregulation of programmed cell death 4 (PDCD4) is associated with aromatase inhibitor resistance and a poor prognosis in estrogen receptor-positive breast cancer. Breast Cancer Research and Treatment 152 29-39. (https://doi.org/10.1007/s10549-015-3446-8)

Chia K, O'Brien M, Brown M \& Lim E 2015 Targeting the androgen receptor in breast cancer. Current Oncology Reports 17 4. (https://doi. org/10.1007/s11912-014-0427-8)

Chu IM, Hengst L \& Slingerland JM 2008 The Cdk inhibitor p27 in human cancer: prognostic potential and relevance to anticancer therapy. Nature Reviews Cancer 8 253-267. (https://doi.org/10.1038/ $\operatorname{nrc2347)}$
Chumsri S 2015 Clinical utilities of aromatase inhibitors in breast cancer. International Journal of Women's Health 7 493-499. (https:// doi.org/10.2147/IJWH.S69907)

Collins LC, Cole KS, Marotti JD, Hu R, Schnitt SJ \& Tamimi RM 2011 Androgen receptor expression in breast cancer in relation to molecular phenotype: results from the Nurses' Health Study. Modern Pathology 24 924-931. (https://doi.org/10.1038/ modpathol.2011.54)

Cook KL \& Clarke R 2014 Estrogen receptor-alpha signaling and localization regulates autophagy and unfolded protein response activation in ER+ breast cancer. Receptors and Clinical Investigation $\mathbf{1}$ e316. (https://doi.org/10.14800/rci.316)

Cook KL, Shajahan AN \& Clarke R 2011 Autophagy and endocrine resistance in breast cancer. Expert Review of Anticancer Therapy $\mathbf{1 1}$ 1283-1294. (https://doi.org/10.1586/era.11.111)

Cook KL, Shajahan AN, Warri A, Jin L, Hilakivi-Clarke LA \& Clarke R 2012 Glucose-regulated protein 78 controls cross-talk between apoptosis and autophagy to determine antiestrogen responsiveness. Cancer Research 72 3337-3349. (https://doi.org/10.1158/0008-5472. CAN-12-0269)

Cook KL, Clarke PA, Parmar J, Hu R, Schwartz-Roberts JL, Abu-Asab M, Warri A, Baumann WT \& Clarke R 2014 Knockdown of estrogen receptor-alpha induces autophagy and inhibits antiestrogenmediated unfolded protein response activation, promoting ROSinduced breast cancer cell death. FASEB Journal 28 3891-3905. (https://doi.org/10.1096/fj.13-247353)

Creighton CJ, Fu X, Hennessy BT, Casa AJ, Zhang Y, GonzalezAngulo AM, Lluch A, Gray JW, Brown PH, Hilsenbeck SG, et al. 2010 Proteomic and transcriptomic profiling reveals a link between the PI3K pathway and lower estrogen-receptor (ER) levels and activity in ER+ breast cancer. Breast Cancer Research 12 R40. (https://doi. org/10.1186/bcr2594)

Cristofanilli M, Turner NC, Bondarenko I, Ro J, Im SA, Masuda N, Colleoni M, DeMichele A, Loi S, Verma S, et al. 2016 Fulvestrant plus palbociclib versus fulvestrant plus placebo for treatment of hormone-receptor-positive, HER2-negative metastatic breast cancer that progressed on previous endocrine therapy (PALOMA-3): final analysis of the multicentre, double-blind, phase 3 randomised controlled trial. Lancet Oncology 17 425-439. (https://doi. org/10.1016/S1470-2045(15)00613-0)

Dalby KN, Tekedereli I, Lopez-Berestein G \& Ozpolat B 2010 Targeting the prodeath and prosurvival functions of autophagy as novel therapeutic strategies in cancer. Autophagy 6 322-329. (https://doi. org/10.4161/auto.6.3.11625)

Demers LM, Melby JC, Wilson TE, Lipton A, Harvey HA \& Santen RJ 1990 The effects of CGS 16949A, an aromatase inhibitor on adrenal mineralocorticoid biosynthesis. Journal of Clinical Endocrinology and Metabolism 70 1162-1166.

Dowling RJ, Topisirovic I, Alain T, Bidinosti M, Fonseca BD, Petroulakis E, Wang X, Larsson O, Selvaraj A, Liu Y, et al. 2010 mTORC1-mediated cell proliferation, but not cell growth, controlled by the 4E-BPs. Science 328 1172-1176. (https://doi.org/10.1126/ science.1187532)

Dowsett M \& Coombes RC 1994 Second generation aromatase inhibitor - 4-hydroxyandrostenedione. Breast Cancer Research and Treatment 30 81-87. (https://doi.org/10.1007/BF00682742)

Early Breast Cancer Trialists' Collaborative Group, Davies C, Godwin J, Gray R, Clarke M, Cutter D, Darby S, McGale P, Pan HC, Taylor C, et al. 2011 Relevance of breast cancer hormone receptors and other factors to the efficacy of adjuvant tamoxifen: patient-level metaanalysis of randomised trials. Lancet 378 771-784. (https://doi. org/10.1016/S0140-6736(11)60993-8)

Early Breast Cancer Trialists' Collaborative Group, Dowsett M, Forbes JF, Bradley R, Ingle J, Aihara T, Bliss J, Boccardo F, Coates A, Coombes RC, et al. 2015 Aromatase inhibitors versus tamoxifen in early breast cancer: patient-level meta-analysis of the randomised 
trials. Lancet 386 1341-1352. (https://doi.org/10.1016/S01406736(15)61074-1)

Elebro K, Borgquist S, Simonsson M, Markkula A, Jirstrom K, Ingvar C, Rose C \& Jernstrom H 2015 Combined androgen and estrogen receptor status in breast cancer: treatment prediction and prognosis in a population-based prospective cohort. Clinical Cancer Research $\mathbf{2 1}$ 3640-3650. (https://doi.org/10.1158/1078-0432.CCR-14-2564)

Ellis MJ, Gao F, Dehdashti F, Jeffe DB, Marcom PK, Carey LA, Dickler MN, Silverman P, Fleming GF, Kommareddy A, et al. 2009 Lower-dose vs high-dose oral estradiol therapy of hormone receptorpositive, aromatase inhibitor-resistant advanced breast cancer: a phase 2 randomized study. JAMA 302 774-780. (https://doi. org/10.1001/jama.2009.1204)

Ellis MJ, Lin L, Crowder R, Tao Y, Hoog J, Snider J, Davies S, DeSchryver K, Evans DB, Steinseifer J, et al. 2010 Phosphatidylinositol-3-kinase alpha catalytic subunit mutation and response to neoadjuvant endocrine therapy for estrogen receptor positive breast cancer. Breast Cancer Research and Treatment 119 379-390. (https:// doi.org/10.1007/s10549-009-0575-y)

Ellis MJ, Llombart-Cussac A, Feltl D, Dewar JA, Jasiowka M, Hewson N, Rukazenkov Y \& Robertson JF 2015 Fulvestrant 500 mg versus anastrozole $1 \mathrm{mg}$ for the first-line treatment of advanced breast cancer: overall survival analysis from the phase II FIRST study. Journal of Clinical Oncology 33 3781-3787. (https://doi.org/10.1200/ JCO.2015.61.5831)

Fanning SW, Mayne CG, Dharmarajan V, Carlson KE, Martin TA, Novick SJ, Toy W, Green B, Panchamukhi S, Katzenellenbogen BS, et al. 2016 Estrogen receptor alpha somatic mutations Y537S and D538G confer breast cancer endocrine resistance by stabilizing the activating function-2 binding conformation. eLife $\mathbf{5}$ e12792. (https:// doi.org/10.7554/eLife.12792)

Finn RS, Crown JP, Lang I, Boer K, Bondarenko IM, Kulyk SO, Ettl J, Patel R, Pinter T, Schmidt M, et al. 2014 Final results of a randomized Phase II study of PD 0332991, a cyclin-dependent kinase (CDK)-4/6 inhibitor, in combination with letrozole vs letrozole alone for first-line treatment of ER+/HER2-advanced breast cancer (PALOMA-1; TRIO-18). Cancer Research 74 (19 Suppl) CT101. (https:// doi.org/10.1158/1538-7445.AM2014-CT101)

Finn RS, Crown JP, Lang I, Boer K, Bondarenko IM, Kulyk SO, Ettl J, Patel R, Pinter T, Schmidt M, et al. 2015 The cyclin-dependent kinase $4 / 6$ inhibitor palbociclib in combination with letrozole versus letrozole alone as first-line treatment of oestrogen receptor-positive, HER2-negative, advanced breast cancer (PALOMA-1/TRIO-18): a randomised phase 2 study. Lancet Oncology 16 25-35. (https://doi. org/10.1016/S1470-2045(14)71159-3)

Flageng MH, Larionov A, Geisler J, Knappskog S, Prestvik WS, Bjorkoy G, Lilleng PK, Dixon JM, Miller WR, Lonning PE, et al. 2017 Treatment with aromatase inhibitors stimulates the expression of epidermal growth factor receptor- 1 and neuregulin 1 in ER positive/ HER-2/neu non-amplified primary breast cancers. Journal of Steroid Biochemistry and Molecular Biology 165 228-235. (https://doi. org/10.1016/j.jsbmb.2016.06.011)

Fox EM, Miller TW, Balko JM, Kuba MG, Sanchez V, Smith RA, Liu S, Gonzalez-Angulo AM, Mills GB, Ye F, et al. 2011 A kinome-wide screen identifies the insulin/IGF-I receptor pathway as a mechanism of escape from hormone dependence in breast cancer. Cancer Research 71 6773-6784. (https://doi.org/10.1158/0008-5472.CAN-111295)

Fox EM, Kuba MG, Miller TW, Davies BR \& Arteaga CL 2013 Autocrine IGF-I/insulin receptor axis compensates for inhibition of AKT in ER-positive breast cancer cells with resistance to estrogen deprivation. Breast Cancer Research 15 R55. (https://doi.org/10.1186/ bcr3449)

Frasor J, Stossi F, Danes JM, Komm B, Lyttle CR \& Katzenellenbogen BS 2004 Selective estrogen receptor modulators: discrimination of agonistic versus antagonistic activities by gene expression profiling in breast cancer cells. Cancer Research 64 1522-1533. (https://doi. org/10.1158/0008-5472.CAN-03-3326)

Fribbens C, O'Leary B, Kilburn L, Hrebien S, Garcia-Murillas I, Beaney M, Cristofanilli M, Andre F, Loi S, Loibl S, et al. 2016 Plasma ESR1 mutations and the treatment of estrogen receptor-positive advanced breast cancer. Journal of Clinical Oncology 34 2961-2968. (https://doi.org/10.1200/JCO.2016.67.3061)

Fujii R, Hanamura T, Suzuki T, Gohno T, Shibahara Y, Niwa T, Yamaguchi Y, Ohnuki K, Kakugawa Y, Hirakawa H, et al. 2014 Increased androgen receptor activity and cell proliferation in aromatase inhibitor-resistant breast carcinoma. Journal of Steroid Biochemistry and Molecular Biology 144 513-522. (https://doi. org/10.1016/j.jsbmb.2014.08.019)

Fuqua SA, Fitzgerald SD, Chamness GC, Tandon AK, McDonnell DP, Nawaz Z, O'Malley BW \& McGuire WL 1991 Variant human breast tumor estrogen receptor with constitutive transcriptional activity. Cancer Research 51 105-109.

Ghosh D, Griswold J, Erman M \& Pangborn W 2009 Structural basis for androgen specificity and oestrogen synthesis in human aromatase. Nature 457 219-223. (https://doi.org/10.1038/nature07614)

Ghosh D, Griswold J, Erman M \& Pangborn W 2010 X-ray structure of human aromatase reveals an androgen-specific active site. Journal of Steroid Biochemistry and Molecular Biology 118 197-202. (https://doi. org/10.1016/j.jsbmb.2009.09.012)

Ghosh D, Lo J, Morton D, Valette D, Xi J, Griswold J, Hubbell S, Egbuta C, Jiang W, An J, et al. 2012 Novel aromatase inhibitors by structure-guided design. Journal of Medicinal Chemistry 55 8464-8476. (https://doi.org/10.1021/jm300930n)

Ghosh D, Lo J \& Egbuta C 2016 Recent progress in the discovery of next generation inhibitors of aromatase from the structure-function perspective. Journal of Medicinal Chemistry 59 5131-5148. (https:// doi.org/10.1021/acs.jmedchem.5b01281)

Giuliano M, Schifp R, Osborne CK \& Trivedi MV 2011 Biological mechanisms and clinical implications of endocrine resistance in breast cancer. Breast 20 (Supplement 3) S42-S49. (https://doi. org/10.1016/S0960-9776(11)70293-4)

Gnant M, Pfeiler G, Dubsky PC, Hubalek M, Greil R, Jakesz R, Wette V, Balic M, Haslbauer F, Melbinger E, et al. 2015 Adjuvant denosumab in breast cancer (ABCSG-18): a multicentre, randomised, doubleblind, placebo-controlled trial. Lancet 386 433-443. (https://doi. org/10.1016/S0140-6736(15)60995-3)

Goldvaser H, Barnes TA, Seruga B, Cescon DW, Ocana A, Ribnikar D \& Amir E 2018 Toxicity of extended adjuvant therapy with aromatase inhibitors in early breast cancer: a systematic review and metaanalysis. Journal of the National Cancer Institute 110 31-39. (https:// doi.org/10.1093/jnci/djx141)

Greenspan SL, Vujevich KT, Brufsky A, Lembersky BC, van Londen GJ, Jankowitz RC, Puhalla SL, Rastogi P \& Perera S 2015 Prevention of bone loss with risedronate in breast cancer survivors: a randomized, controlled clinical trial. Osteoporosis International 26 1857-1864. (https://doi.org/10.1007/s00198-015-3100-7)

Griffiths CT, Hall TC, Saba Z, Barlow JJ \& Nevinny HB 1973 Preliminary trial of aminoglutethimide in breast cancer. Cancer 32 31-37. (https://doi.org/10.1002/1097-0142(197307)32:1<31::AIDCNCR2820320104>3.0.CO;2-5)

Guo S \& Sonenshein GE 2004 Forkhead box transcription factor FOXO3a regulates estrogen receptor alpha expression and is repressed by the Her-2/neu/phosphatidylinositol 3-kinase/Akt signaling pathway. Molecular and Cellular Biology 24 8681-8690. (https://doi.org/10.1128/MCB.24.19.8681-8690.2004)

Hanamura T, Niwa T, Nishikawa S, Konno H, Gohno T, Tazawa C, Kobayashi Y, Kurosumi M, Takei H, Yamaguchi Y, et al. 2013 Androgen metabolite-dependent growth of hormone receptorpositive breast cancer as a possible aromatase inhibitor-resistance mechanism. Breast Cancer Research and Treatment 139 731-740. (https://doi.org/10.1007/s10549-013-2595-x) (c) 2018 Society for Endocrinology Published by Bioscientifica Ltd. Printed in Great Britain 
He C \& Klionsky DJ 2009 Regulation mechanisms and signaling pathways of autophagy. Annual Review of Genetics 43 67-93. (https:// doi.org/10.1146/annurev-genet-102808-114910)

Heldring N, Pike A, Andersson S, Matthews J, Cheng G, Hartman J, Tujague M, Strom A, Treuter E, Warner M, et al. 2007 Estrogen receptors: how do they signal and what are their targets. Physiological Reviews 87 905-931. (https://doi.org/10.1152/physrev.00026.2006)

Hoeflich KP, Guan J, Edgar KA, O’Brien C, Savage H, Wilson TR, Neve RM, Friedman LS \& Wallin JJ 2016 The PI3K inhibitor taselisib overcomes letrozole resistance in a breast cancer model expressing aromatase. Genes and Cancer 7 73-85. (https://doi.org/10.18632/ genesandcancer.100)

Hole S, Pedersen AM, Hansen SK, Lundqvist J, Yde CW \& Lykkesfeldt AE $2015 a$ New cell culture model for aromatase inhibitor-resistant breast cancer shows sensitivity to fulvestrant treatment and cross-resistance between letrozole and exemestane. International Journal of Oncology 46 1481-1490. (https://doi.org/10.3892/ijo.2015.2850)

Hole S, Pedersen AM, Lykkesfeldt AE \& Yde CW 2015b Aurora kinase A and $\mathrm{B}$ as new treatment targets in aromatase inhibitor-resistant breast cancer cells. Breast Cancer Research and Treatment 149 715-726. (https://doi.org/10.1007/s10549-015-3284-8)

Holst F, Stahl PR, Ruiz C, Hellwinkel O, Jehan Z, Wendland M, Lebeau A, Terracciano L, Al-Kuraya K, Janicke F, et al. 2007 Estrogen receptor alpha (ESR1) gene amplification is frequent in breast cancer. Nature Genetics 39 655-660. (https://doi.org/10.1038/ng2006)

Hortobagyi GN, Stemmer SM, Burris HA, Yap YS, Sonke GS, PaluchShimon S, Campone M, Blackwell KL, Andre F, Winer EP, et al. 2016 Ribociclib as first-line therapy for HR-positive, advanced breast cancer. New England Journal of Medicine 375 1738-1748. (https://doi. org/10.1056/NEJMoa1609709)

Howell A, Cuzick J, Baum M, Buzdar A, Dowsett M, Forbes JF, HoctinBoes G, Houghton J, Locker GY, Tobias JS, et al. 2005 Results of the ATAC (Arimidex, Tamoxifen, Alone or in Combination) trial after completion of 5 years' adjuvant treatment for breast cancer. Lancet 365 60-62. (https://doi.org/10.1016/S0140-6736(04)17666-6)

Htun H, Holth LT, Walker D, Davie JR \& Hager GL 1999 Direct visualization of the human estrogen receptor alpha reveals a role for ligand in the nuclear distribution of the receptor. Molecular Biology of the Cell 10 471-486. (https://doi.org/10.1091/mbc.10.2.471)

Hui R, Finney GL, Carroll JS, Lee CS, Musgrove EA \& Sutherland RL 2002 Constitutive overexpression of cyclin D1 but not cyclin E confers acute resistance to antiestrogens in T-47D breast cancer cells. Cancer Research 62 6916-6923.

Jelovac D, Sabnis G, Long BJ, Macedo L, Goloubeva OG \& Brodie AM 2005 Activation of mitogen-activated protein kinase in xenografts and cells during prolonged treatment with aromatase inhibitor letrozole. Cancer Research 65 5380-5389. (https://doi. org/10.1158/0008-5472.CAN-04-4502)

Jeng MH, Yue W, Eischeid A, Wang JP \& Santen RJ 2000 Role of MAP kinase in the enhanced cell proliferation of long term estrogen deprived human breast cancer cells. Breast Cancer Research and Treatment 62 167-175. (https://doi.org/10.1023/A:1006406030612)

Jeselsohn R, Buchwalter G, De Angelis C, Brown M \& Schiff R 2015 ESR1 mutations-a mechanism for acquired endocrine resistance in breast cancer. Nature Reviews Clinical Oncology 12 573-583. (https:// doi.org/10.1038/nrclinonc.2015.117)

Jia M, Dahlman-Wright K \& Gustafsson JA 2015 Estrogen receptor alpha and beta in health and disease. Best Practice and Research Clinical Endocrinology and Metabolism 29 557-568. (https://doi.org/10.1016/j. beem.2015.04.008)

Kato S, Endoh H, Masuhiro Y, Kitamoto T, Uchiyama S, Sasaki H, Masushige S, Gotoh Y, Nishida E, Kawashima H, et al. 1995 Activation of the estrogen receptor through phosphorylation by mitogen-activated protein kinase. Science 270 1491-1494. (https:// doi.org/10.1126/science.270.5241.1491)
Khosrow-Khavar F, Filion KB, Al-Qurashi S, Torabi N, Bouganim N, Suissa S \& Azoulay L 2017 Cardiotoxicity of aromatase inhibitors and tamoxifen in postmenopausal women with breast cancer: a systematic review and meta-analysis of randomized controlled trials. Annals of Oncology 28 487-496. (https://doi.org/10.1093/annonc/ mdw673)

Kim MJ, Kim TH \& Lee HH 2015 G-protein coupled estrogen receptor (GPER/GPR30) and women's health. Journal of Menopausal Medicine 21 79-81. (https://doi.org/10.6118/jmm.2015.21.2.79)

Kubo M, Kanaya N, Petrossian K, Ye J, Warden C, Liu Z, Nishimura R, Osako T, Okido M, Shimada K, et al. 2013 Inhibition of the proliferation of acquired aromatase inhibitor-resistant breast cancer cells by histone deacetylase inhibitor LBH589 (panobinostat). Breast Cancer Research and Treatment 137 93-107. (https://doi.org/10.1007/ s10549-012-2332-x)

Lai A, Kahraman M, Govek S, Nagasawa J, Bonnefous C, Julien J, Douglas K, Sensintaffar J, Lu N, Lee KJ, et al. 2015 Identification of GDC-0810 (ARN-810), an orally bioavailable selective estrogen receptor degrader (SERD) that demonstrates robust activity in tamoxifen-resistant breast cancer xenografts. Journal of Medicinal Chemistry 58 4888-4904. (https://doi.org/10.1021/acs. jmedchem.5b00054)

Lattrich C, Stegerer A, Haring J, Schuler S, Ortmann O \& Treeck O 2013 Estrogen receptor beta agonists affect growth and gene expression of human breast cancer cell lines. Steroids 78 195-202. (https://doi. org/10.1016/j.steroids.2012.10.014)

Li L, Haynes MP \& Bender JR 2003 Plasma membrane localization and function of the estrogen receptor alpha variant (ER46) in human endothelial cells. PNAS 100 4807-4812. (https://doi.org/10.1073/ pnas.0831079100)

Li S, Shen D, Shao J, Crowder R, Liu W, Prat A, He X, Liu S, Hoog J, Lu C, et al. 2013 Endocrine-therapy-resistant ESR1 variants revealed by genomic characterization of breast-cancer-derived xenografts. Cell Reports 4 1116-1130. (https://doi.org/10.1016/j.celrep.2013.08.022)

Liu J, Zheng S, Akerstrom VL, Yuan C, Ma Y, Zhong Q, Zhang C, Zhang Q, Guo S, Ma P, et al. 2016 Fulvestrant-3 boronic acid (ZB716): an orally bioavailable selective estrogen receptor downregulator (SERD). Journal of Medicinal Chemistry 59 8134-8140. (https://doi.org/10.1021/acs.jmedchem.6b00753)

Lonning PE 2008 Exploring the lack of cross-resistance between aromatase inhibitors: evidence for a difference? Anticancer Drugs 19 (Supplement 2) S11-S13. (https://doi.org/10.1097/01. cad.0000277875.81122.25)

Lonning PE 2009 Lack of complete cross-resistance between different aromatase inhibitors; a real finding in search for an explanation? European Journal of Cancer 45 527-535. (https://doi.org/10.1016/j. ejca.2008.10.019)

LoRusso PM 2013 Mammalian target of rapamycin as a rational therapeutic target for breast cancer treatment. Oncology 84 43-56. (https://doi.org/10.1159/000343063)

Lui A, New J, Ogony J, Thomas S \& Lewis-Wambi J 2016 Everolimus downregulates estrogen receptor and induces autophagy in aromatase inhibitor-resistant breast cancer cells. BMC Cancer 16487. (https://doi.org/10.1186/s12885-016-2490-z)

Lundgren K, Brown M, Pineda S, Cuzick J, Salter J, Zabaglo L, Howell A, Dowsett M, Landberg G \& Trans Ai 2012 Effects of cyclin D1 gene amplification and protein expression on time to recurrence in postmenopausal breast cancer patients treated with anastrozole or tamoxifen: a TransATAC study. Breast Cancer Research 14 R57. (https://doi.org/10.1186/bcr3161)

Ma Y, Ambannavar R, Stephans J, Jeong J, Dei Rossi A, Liu ML, Friedman AJ, Londry JJ, Abramson R, Beasley EM, et al. 2014 Fusion transcript discovery in formalin-fixed paraffin-embedded human breast cancer tissues reveals a link to tumor progression. PLOS ONE 9 e94202. (https://doi.org/10.1371/journal.pone.0094202)
2018 Society for Endocrinology Published by Bioscientifica Ltd. Printed in Great Britain 
Macedo LF, Guo Z, Tilghman SL, Sabnis GJ, Qiu Y \& Brodie A 2006 Role of androgens on MCF-7 breast cancer cell growth and on the inhibitory effect of letrozole. Cancer Research 66 7775-7782. (https:// doi.org/10.1158/0008-5472.CAN-05-3984)

Macedo LF, Sabnis GJ, Goloubeva OG \& Brodie A 2008 Combination of anastrozole with fulvestrant in the intratumoral aromatase xenograft model. Cancer Research 68 3516-3522. (https://doi.org/10.1158/00085472.CAN-07-6807)

Magnani L, Frige G, Gadaleta RM, Corleone G, Fabris S, Kempe H, Verschure PJ, Barozzi I, Vircillo V, Hong SP, et al. 2017 Acquired CYP19A1 amplification is an early specific mechanism of aromatase inhibitor resistance in ERalpha metastatic breast cancer. Nature Genetics 49 444-450. (https://doi.org/10.1038/ng.3773)

Martin LA, Farmer I, Johnston SR, Ali S, Marshall C \& Dowsett M 2003 Enhanced estrogen receptor (ER) alpha, ERBB2, and MAPK signal transduction pathways operate during the adaptation of MCF-7 cells to long term estrogen deprivation. Journal of Biological Chemistry 278 30458-30468. (https://doi.org/10.1074/jbc.M305226200)

Martín M, Kahan Z, Carrasco E, Bartlett C, Casas M, Gil-Gil M, Muñoz M, Ciruelos E, Ruiz-Borrego M \& Margelí M 2017 Abstract OT2-01-06: phase III study of palbociclib (PD-0332991) in combination with endocrine therapy (exemestane or fulvestrant) versus chemotherapy (capecitabine) in hormonal receptor (HR) positive/HER2 negative metastatic breast cancer (MBC) patients with resistance to aromatase inhibitors. 'The PEARL study' (GEICAM/2013-02). Cancer Research 77 (4 Suppl) OT2-01-06. (https://doi.org/10.1158/1538-7445. SABCS16-OT2-01-06)

Masamura S, Santner SJ, Heitjan DF \& Santen RJ 1995 Estrogen deprivation causes estradiol hypersensitivity in human breast cancer cells. Journal of Clinical Endocrinology and Metabolism 80 2918-2925. (https://doi.org/10.1210/jcem.80.10.7559875)

Masri S, Liu Z, Phung S, Wang E, Yuan YC \& Chen S 2010a The role of microRNA-128a in regulating TGFbeta signaling in letrozole-resistant breast cancer cells. Breast Cancer Research and Treatment 124 89-99. (https://doi.org/10.1007/s10549-009-0716-3)

Masri S, Phung S, Wang X \& Chen S 2010b Molecular characterization of aromatase inhibitor-resistant, tamoxifen-resistant and LTEDaro cell lines. Journal of Steroid Biochemistry and Molecular Biology 118 277-282. (https://doi.org/10.1016/j.jsbmb.2009.10.011)

Massarweh S \& Schiff R 2007 Unraveling the mechanisms of endocrine resistance in breast cancer: new therapeutic opportunities. Clinical Cancer Research 13 1950-1954. (https://doi.org/10.1158/1078-0432. CCR-06-2540)

Mayer IA, Abramson VG, Isakoff SJ, Forero A, Balko JM, Kuba MG, Sanders ME, Yap JT, Van den Abbeele AD, Li Y, et al. 2014 Stand up to cancer phase Ib study of pan-phosphoinositide-3-kinase inhibitor buparlisib with letrozole in estrogen receptor-positive/human epidermal growth factor receptor 2-negative metastatic breast cancer Journal of Clinical Oncology 32 1202-1209. (https://doi.org/10.1200/ JCO.2013.54.0518)

Mehta A \& Tripathy D 2014 Co-targeting estrogen receptor and HER2 pathways in breast cancer. Breast 23 2-9. (https://doi.org/10.1016/j. breast.2013.09.006)

Milla-Santos A, Milla L, Portella J, Rallo L, Pons M, Rodes E, Casanovas \& Puig-Gali M 2003 Anastrozole versus tamoxifen as first-line therapy in postmenopausal patients with hormone-dependent advanced breast cancer: a prospective, randomized, phase III study. American Journal of Clinical Oncology 26 317-322. (https://doi. org/10.1097/01.COC.0000047126.10522.F9)

Miller TW, Hennessy BT, Gonzalez-Angulo AM, Fox EM, Mills GB, Chen H, Higham C, Garcia-Echeverria C, Shyr Y \& Arteaga CL 2010 Hyperactivation of phosphatidylinositol-3 kinase promotes escape from hormone dependence in estrogen receptor-positive human breast cancer. Journal of Clinical Investigation 120 2406-2413. (https://doi.org/10.1172/JCI41680)
Miller TW, Balko JM, Ghazoui Z, Dunbier A, Anderson H, Dowsett M, Gonzalez-Angulo AM, Mills GB, Miller WR, Wu H, et al. 2011 A gene expression signature from human breast cancer cells with acquired hormone independence identifies MYC as a mediator of antiestrogen resistance. Clinical Cancer Research 17 2024-2034. (https://doi. org/10.1158/1078-0432.CCR-10-2567)

Morales M, Santana N, Soria A, Mosquera A, Ordovas J, Novoa J, Betancor P, Valeron PF, Diaz-Chico B \& Chirino R 1996 Effects of tamoxifen on serum lipid and apolipoprotein levels in postmenopausal patients with breast cancer. Breast Cancer Research and Treatment 40 265-270. (https://doi.org/10.1007/BF01806815)

Mouridsen H, Gershanovich M, Sun Y, Perez-Carrion R, Boni C, Monnier A, Apffelstaedt J, Smith R, Sleeboom HP, Janicke F, et al. 2001 Superior efficacy of letrozole versus tamoxifen as first-line therapy for postmenopausal women with advanced breast cancer: results of a phase III study of the International Letrozole Breast Cancer Group. Journal of Clinical Oncology 19 2596-2606. (https:// doi.org/10.1200/JCO.2001.19.10.2596)

Mouridsen H, Gershanovich M, Sun Y, Perez-Carrion R, Boni C, Monnier A, Apffelstaedt J, Smith R, Sleeboom HP, Jaenicke F, et al. 2003 Phase III study of letrozole versus tamoxifen as first-line therapy of advanced breast cancer in postmenopausal women: analysis of survival and update of efficacy from the International Letrozole Breast Cancer Group. Journal of Clinical Oncology 21 2101-2109. (https://doi.org/10.1200/JCO.2003.04.194)

Mouridsen H, Keshaviah A, Coates AS, Rabaglio M, CastiglioneGertsch M, Sun Z, Thurlimann B, Mauriac L, Forbes JF, Paridaens R, et al. 2007 Cardiovascular adverse events during adjuvant endocrine therapy for early breast cancer using letrozole or tamoxifen: safety analysis of BIG 1-98 trial. Journal of Clinical Oncology 25 5715-5722. (https://doi.org/10.1200/JCO.2007.12.1665)

Muluhngwi P \& Klinge CM 2015 Roles for miRNAs in endocrine resistance in breast cancer. Endocrine-Related Cancer 22 R279-R300. (https://doi.org/10.1530/ERC-15-0355)

Musgrove EA \& Sutherland RL 2009 Biological determinants of endocrine resistance in breast cancer. Nature Reviews Cancer 9 631-643. (https://doi.org/10.1038/nrc2713)

Nabholtz JM 2008 Long-term safety of aromatase inhibitors in the treatment of breast cancer. Therapeutics and Clinical Risk Management 4 189-204. (https://doi.org/10.2147/TCRM.S1566)

Nathan L, Shi W, Dinh H, Mukherjee TK, Wang X, Lusis AJ \& Chaudhuri G 2001 Testosterone inhibits early atherogenesis by conversion to estradiol: critical role of aromatase. PNAS 98 3589-3593. (https://doi.org/10.1073/pnas.051003698)

Niu J, Andres G, Kramer K, Kundranda MN, Alvarez RH, Klimant E, Parikh AR, Tan B, Staren ED \& Markman M 2015 Incidence and clinical significance of ESR1 mutations in heavily pretreated metastatic breast cancer patients. OncoTargets and Therapy $\mathbf{8}$ 3323-3328. (https://doi.org/10.2147/OTT.S92443)

O'Shaughnessy J, Campone M, Brain E, Neven P, Hayes D, Bondarenko I, Griffin TW, Martin J, De Porre P, Kheoh T, et al. 2016 Abiraterone acetate, exemestane or the combination in postmenopausal patients with estrogen receptor-positive metastatic breast cancer. Annals of Oncology 27 106-113. (https://doi. org/10.1093/annonc/mdv487)

Ormandy CJ, Musgrove EA, Hui R, Daly RJ \& Sutherland RL 2003 Cyclin D1, EMS1 and 11q13 amplification in breast cancer. Breast Cancer Research and Treatment 78 323-335. (https://doi. org/10.1023/A:1023033708204)

Pagani O, Regan MM, Walley BA, Fleming GF, Colleoni M, Lang I, Gomez HL, Tondini C, Burstein HJ, Perez EA, et al. 2014 Adjuvant exemestane with ovarian suppression in premenopausal breast cancer. New England Journal of Medicine 371 107-118. (https://doi. org/10.1056/NEJMoa1404037)

Paridaens R, Therasse P, Dirix L, Beex L, Piccart M, Cameron D, Cufer T, Roozendaal K, Nooij M \& Mattiacci MR 2004 First line hormonal
(C) 2018 Society for Endocrinology Published by Bioscientifica Ltd. Printed in Great Britain 
treatment (HT) for metastatic breast cancer (MBC) with exemestane (E) or tamoxifen (T) in postmenopausal patients (pts) - a randomized phase III trial of the EORTC Breast Group. Journal of Clinical Oncology 22 515. (https://doi.org/10.1200/jco.2004.22.14_ suppl.515)

Paridaens RJ, Dirix LY, Beex LV, Nooij M, Cameron DA, Cufer T, Piccart MJ, Bogaerts J \& Therasse P 2008 Phase III study comparing exemestane with tamoxifen as first-line hormonal treatment of metastatic breast cancer in postmenopausal women: the European Organisation for Research and Treatment of Cancer Breast Cancer Cooperative Group. Journal of Clinical Oncology 26 4883-4890. (https://doi.org/10.1200/JCO.2007.14.4659)

Paruthiyil S, Parmar H, Kerekatte V, Cunha GR, Firestone GL \& Leitman DC 2004 Estrogen receptor beta inhibits human breast cancer cell proliferation and tumor formation by causing a G2 cell cycle arrest. Cancer Research 64 423-428. (https://doi. org/10.1158/0008-5472.CAN-03-2446)

Perez-Tenorio G, Alkhori L, Olsson B, Waltersson MA, Nordenskjold B, Rutqvist LE, Skoog L \& Stal O 2007 PIK3CA mutations and PTEN loss correlate with similar prognostic factors and are not mutually exclusive in breast cancer. Clinical Cancer Research 13 3577-3584. (https://doi.org/10.1158/1078-0432.CCR-06-1609)

Peters AA, Buchanan G, Ricciardelli C, Bianco-Miotto T, Centenera MM, Harris JM, Jindal S, Segara D, Jia L, Moore NL, et al. 2009 Androgen receptor inhibits estrogen receptor-alpha activity and is prognostic in breast cancer. Cancer Research 69 6131-6140. (https://doi. org/10.1158/0008-5472.CAN-09-0452)

Piccart M, Hortobagyi GN, Campone M, Pritchard KI, Lebrun F, Ito Y, Noguchi S, Perez A, Rugo HS, Deleu I, et al. 2014 Everolimus plus exemestane for hormone-receptor-positive, human epidermal growth factor receptor-2-negative advanced breast cancer: overall survival results from BOLERO-2dagger. Annals of Oncology 25 2357-2362. (https://doi.org/10.1093/annonc/mdu456)

Pick E, Kluger Y, Giltnane JM, Moeder C, Camp RL, Rimm DL \& Kluger HM 2007 High HSP90 expression is associated with decreased survival in breast cancer. Cancer Research 67 2932-2937. (https://doi. org/10.1158/0008-5472.CAN-06-4511)

Proverbs-Singh T, Feldman JL, Morris MJ, Autio KA \& Traina TA 2015 Targeting the androgen receptor in prostate and breast cancer: several new agents in development. Endocrine-Related Cancer 22 R87-R106. (https://doi.org/10.1530/ERC-14-0543)

Rechoum Y, Rovito D, Iacopetta D, Barone I, Ando S, Weigel NL, O'Malley BW, Brown PH \& Fuqua SA 2014 AR collaborates with ERalpha in aromatase inhibitor-resistant breast cancer. Breast Cancer Research and Treatment 147 473-485. (https://doi.org/10.1007/ s10549-014-3082-8)

Regan MM, Pagani O, Francis PA, Fleming GF, Walley BA, Kammler R, Dell'Orto P, Russo L, Szoke J, Doimi F, et al. 2015 Predictive value and clinical utility of centrally assessed ER, PgR, and Ki-67 to select adjuvant endocrine therapy for premenopausal women with hormone receptor-positive, HER2-negative early breast cancer: TEXT and SOFT trials. Breast Cancer Research and Treatment 154 275-286. (https://doi.org/10.1007/s10549-015-3612-z)

Reis SE, Costantino JP, Wickerham DL, Tan-Chiu E, Wang J \&

Kavanah M 2001 Cardiovascular effects of tamoxifen in women with and without heart disease: breast cancer prevention trial. National Surgical Adjuvant Breast and Bowel Project Breast Cancer Prevention Trial Investigators. Journal of the National Cancer Institute 93 16-21. (https://doi.org/10.1093/jnci/93.1.16)

Robertson JF, Llombart-Cussac A, Rolski J, Feltl D, Dewar J, Macpherson E, Lindemann J \& Ellis MJ 2009 Activity of fulvestrant $500 \mathrm{mg}$ versus anastrozole $1 \mathrm{mg}$ as first-line treatment for advanced breast cancer: results from the FIRST study. Journal of Clinical Oncology 27 4530-4535. (https://doi.org/10.1200/JCO.2008.21.1136)

Robertson JF, Lindemann JP, Llombart-Cussac A, Rolski J, Feltl D, Dewar J, Emerson L, Dean A \& Ellis MJ 2012 Fulvestrant 500 mg versus anastrozole $1 \mathrm{mg}$ for the first-line treatment of advanced breast cancer: follow-up analysis from the randomized 'FIRST' study. Breast Cancer Research and Treatment 136 503-511. (https://doi. org/10.1007/s10549-012-2192-4)

Robertson JFR, Bondarenko IM, Trishkina E, Dvorkin M, Panasci L, Manikhas A, Shparyk Y, Cardona-Huerta S, Cheung KL, PhilcoSalas MJ, et al. 2016 Fulvestrant $500 \mathrm{mg}$ versus anastrozole $1 \mathrm{mg}$ for hormone receptor-positive advanced breast cancer (FALCON): an international, randomised, double-blind, phase 3 trial. Lancet $\mathbf{3 8 8}$ 2997-3005. (https://doi.org/10.1016/S0140-6736(16)32389-3)

Robinson DR, Wu YM, Vats P, Su F, Lonigro RJ, Cao X, KalyanaSundaram S, Wang R, Ning Y, Hodges L, et al. 2013 Activating ESR1 mutations in hormone-resistant metastatic breast cancer. Nature Genetics 45 1446-1451. (https://doi.org/10.1038/ng.2823)

Roodi N, Bailey LR, Kao WY, Verrier CS, Yee CJ, Dupont WD \& Parl FF 1995 Estrogen receptor gene analysis in estrogen receptorpositive and receptor-negative primary breast cancer. Journal of the National Cancer Institute 87 446-451. (https://doi.org/10.1093/ jnci/87.6.446)

Saal LH, Johansson P, Holm K, Gruvberger-Saal SK, She QB, Maurer M, Koujak S, Ferrando AA, Malmstrom P, Memeo L, et al. 2007 Poor prognosis in carcinoma is associated with a gene expression signature of aberrant PTEN tumor suppressor pathway activity. PNAS 104 7564-7569. (https://doi.org/10.1073/pnas.0702507104)

Sabnis G \& Brodie A 2010 Understanding resistance to endocrine agents: molecular mechanisms and potential for intervention. Clinical Breast Cancer 10 E6-E15. (https://doi.org/10.3816/CBC.2010.n.014)

Sabnis G, Schayowitz A, Goloubeva O, Macedo L \& Brodie A 2009 Trastuzumab reverses letrozole resistance and amplifies the sensitivity of breast cancer cells to estrogen. Cancer Research 69 1416-1428. (https://doi.org/10.1158/0008-5472.CAN-08-0857)

Sabnis G, Goloubeva O, Gilani R, Macedo L \& Brodie A 2010 Sensitivity to the aromatase inhibitor letrozole is prolonged after a 'break' in treatment. Molecular Cancer Therapeutics 9 46-56. (https://doi. org/10.1158/1535-7163.MCT-09-0696)

Sabnis GJ, Goloubeva OG, Kazi AA, Shah P \& Brodie AH 2013a HDAC inhibitor entinostat restores responsiveness of letrozole-resistant MCF-7Ca xenografts to aromatase inhibitors through modulation of Her-2. Molecular Cancer Therapeutics 12 2804-2816. (https://doi. org/10.1158/1535-7163.MCT-13-0345)

Sabnis GJ, Kazi A, Golubeva O, Shah P \& Brodie A 2013b Effect of selumetinib on the growth of anastrozole-resistant tumors. Breast Cancer Research and Treatment 138 699-708. (https://doi.org/10.1007/ s10549-013-2474-5)

Santen RJ 1981 Suppression of estrogens with aminoglutethimide and hydrocortisone (medical adrenalectomy) as treatment of advanced breast carcinoma: a review. Breast Cancer Research and Treatment 1 183-202. (https://doi.org/10.1007/BF01806259)

Santen RJ, Song RX, Zhang Z, Kumar R, Jeng MH, Masamura S, Lawrence J Jr, MacMahon LP, Yue W \& Berstein L 2005 Adaptive hypersensitivity to estrogen: mechanisms and clinical relevance to aromatase inhibitor therapy in breast cancer treatment. Journal of Steroid Biochemistry and Molecular Biology 95 155-165. (https://doi. org/10.1016/j.jsbmb.2005.04.025)

Santen RJ, Fan P, Zhang Z, Bao Y, Song RX \& Yue W 2009 Estrogen signals via an extra-nuclear pathway involving IGF-1R and EGFR in tamoxifen-sensitive and -resistant breast cancer cells. Steroids $\mathbf{7 4}$ 586-594. (https://doi.org/10.1016/j.steroids.2008.11.020)

Scaling AL, Prossnitz ER \& Hathaway HJ 2014 GPER mediates estrogeninduced signaling and proliferation in human breast epithelial cells and normal and malignant breast. Hormones and Cancer 5 146-160. (https://doi.org/10.1007/s12672-014-0174-1)

Schech AJ, Shah P, Yu S, Sabnis GJ, Goloubeva O, Rosenblatt P, Kazi A, Chumsri S \& Brodie A 2015 Histone deacetylase inhibitor entinostat in combination with a retinoid downregulates HER2 and reduces the tumor initiating cell population in aromatase inhibitor-resistant
2018 Society for Endocrinology Published by Bioscientifica Ltd. Printed in Great Britain 
breast cancer. Breast Cancer Research and Treatment 152 499-508. (https://doi.org/10.1007/s10549-015-3442-z)

Schiavon G, Hrebien S, Garcia-Murillas I, Cutts RJ, Pearson A, Tarazona N, Fenwick K, Kozarewa I, Lopez-Knowles E, Ribas R, et al. 2015 Analysis of ESR1 mutation in circulating tumor DNA demonstrates evolution during therapy for metastatic breast cancer. Science Translational Medicine 7 313ra182. (https://doi.org/10.1126/ scitranslmed.aac7551)

Schieweck K, Bhatnagar AS \& Matter A 1988 CGS 16949A, a new nonsteroidal aromatase inhibitor: effects on hormone-dependent and -independent tumors in vivo. Cancer Research 48 834-838.

Schmid P, Pinder SE, Wheatley D, Macaskill J, Zammit C, Hu J, Price R, Bundred N, Hadad S, Shia A, et al. 2016 Phase II randomized preoperative window-of-opportunity study of the PI3K inhibitor pictilisib plus anastrozole compared with anastrozole alone in patients with estrogen receptor-positive breast cancer. Journal of Clinical Oncology 34 1987-1994. (https://doi.org/10.1200/ JCO.2015.63.9179)

Schwartzberg LS, Yardley D, Elias A, Patel M, LoRusso PM, Burris HA, Gucalp A, Peterson A, Blaney M, Steinberg J, et al. 2017 A phase I/Ib study of enzalutamide alone and in combination with endocrine therapies in women with advanced breast cancer. Clinical Cancer Research 23 4046-4054. (https://doi.org/10.1158/1078-0432.CCR-162339)

Sikora MJ, Cordero KE, Larios JM, Johnson MD, Lippman ME \& Rae JM 2009 The androgen metabolite 5alpha-androstane-3beta,17beta-diol (3betaAdiol) induces breast cancer growth via estrogen receptor: implications for aromatase inhibitor resistance. Breast Cancer Research and Treatment 115 289-296. (https://doi.org/10.1007/s10549-0080080-8)

Sikora MJ, Strumba V, Lippman ME, Johnson MD \& Rae JM 2012 Mechanisms of estrogen-independent breast cancer growth driven by low estrogen concentrations are unique versus complete estrogen deprivation. Breast Cancer Research and Treatment 134 1027-1039. (https://doi.org/10.1007/s10549-012-2032-6)

Simoncini T, Hafezi-Moghadam A, Brazil DP, Ley K, Chin WW \& Liao JK 2000 Interaction of oestrogen receptor with the regulatory subunit of phosphatidylinositol-3-OH kinase. Nature 407 538-541. (https:// doi.org/10.1038/35035131)

Sobral AF, Amaral C, Correia-da-Silva G \& Teixeira N 2016 Unravelling exemestane: from biology to clinical prospects. Journal of Steroid Biochemistry and Molecular Biology 163 1-11. (https://doi. org/10.1016/j.jsbmb.2016.03.019)

Steger G, Bartsch R, Pfeiler G, Petru E, Greil R, Helfgott R, Egle D, Öhler L, Lang A, Tinchon C, et al. 2017 Abstract P4-22-20: efficacy and safety of everolimus plus exemestane in HR+, HER2- advanced breast cancer progressing on/after prior endocrine therapy, in routine clinical practice: 2nd interim analysis from STEPAUT. Cancer Research 77 P4-22-20. (https://doi.org/10.1158/1538-7445.SABCS16-P4-22-20)

Stemke-Hale K, Gonzalez-Angulo AM, Lluch A, Neve RM, Kuo WL, Davies M, Carey M, Hu Z, Guan Y, Sahin A, et al. 2008 An integrative genomic and proteomic analysis of PIK3CA, PTEN, and AKT mutations in breast cancer. Cancer Research 68 6084-6091. (https://doi.org/10.1158/0008-5472.CAN-07-6854)

Stephen RL, Shaw LE, Larsen C, Corcoran D \& Darbre PD 2001 Insulinlike growth factor receptor levels are regulated by cell density and by long term estrogen deprivation in MCF7 human breast cancer cells. Journal of Biological Chemistry 276 40080-40086. (https://doi. org/10.1074/jbc.M105892200)

Swaby RF \& Jordan VC 2008 Low-dose estrogen therapy to reverse acquired antihormonal resistance in the treatment of breast cancer. Clinical Breast Cancer 8 124-133. (https://doi.org/10.3816/ CBC.2008.n.012)

Tilghman SL, Townley I, Zhong Q, Carriere PP, Zou J, Llopis SD, Preyan LC, Williams CC, Skripnikova E, Bratton MR, et al. 2013 Proteomic signatures of acquired letrozole resistance in breast cancer: suppressed estrogen signaling and increased cell motility and invasiveness. Molecular and Cellular Proteomics 12 2440-2455. (https://doi.org/10.1074/mcp.M112.023861)

Toh PP, Luo S, Menzies FM, Rasko T, Wanker EE \& Rubinsztein DC 2013 Myc inhibition impairs autophagosome formation. Human Molecular Genetics 22 5237-5248. (https://doi.org/10.1093/hmg/ddt381)

Toy W, Shen Y, Won H, Green B, Sakr RA, Will M, Li Z, Gala K, Fanning S, King TA, et al. 2013 ESR1 ligand-binding domain mutations in hormone-resistant breast cancer. Nature Genetics $\mathbf{4 5}$ 1439-1445. (https://doi.org/10.1038/ng.2822)

Turner N, Pearson A, Sharpe R, Lambros M, Geyer F, Lopez-Garcia MA, Natrajan R, Marchio C, Iorns E, Mackay A, et al. 2010 FGFR1 amplification drives endocrine therapy resistance and is a therapeutic target in breast cancer. Cancer Research 70 2085-2094. (https://doi.org/10.1158/0008-5472.CAN-09-3746)

Tyson JJ, Baumann WT, Chen C, Verdugo A, Tavassoly I, Wang Y, Weiner LM \& Clarke R 2011 Dynamic modelling of oestrogen signalling and cell fate in breast cancer cells. Nature Reviews Cancer 11 523-532. (https://doi.org/10.1038/nrc3081)

Ueno T, Saji S, Sugimoto M, Masuda N, Kuroi K, Sato N, Takei H, Yamamoto Y, Ohno S, Yamashita H, et al. 2016 Clinical significance of the expression of autophagy-associated marker, beclin 1, in breast cancer patients who received neoadjuvant endocrine therapy. $B M C$ Cancer 16 230. (https://doi.org/10.1186/s12885-016-2270-9)

van de Velde CJ, Rea D, Seynaeve C, Putter H, Hasenburg A, Vannetzel JM, Paridaens R, Markopoulos C, Hozumi Y, Hille ET, et al. 2011 Adjuvant tamoxifen and exemestane in early breast cancer (TEAM): a randomised phase 3 trial. Lancet 377 321-331. (https:// doi.org/10.1016/S0140-6736(10)62312-4)

Veeraraghavan J, Tan Y, Cao XX, Kim JA, Wang X, Chamness GC, Maiti SN, Cooper LJ, Edwards DP, Contreras A, et al. 2014 Recurrent ESR1-CCDC170 rearrangements in an aggressive subset of oestrogen receptor-positive breast cancers. Nature Communications 54577. (https://doi.org/10.1038/ncomms5577)

Vilquin P, Villedieu M, Grisard E, Ben Larbi S, Ghayad SE, Heudel PE, Bachelot T, Corbo L, Treilleux I, Vendrell JA, et al. 2013 Molecular characterization of anastrozole resistance in breast cancer: pivotal role of the Akt/mTOR pathway in the emergence of de novo or acquired resistance and importance of combining the allosteric Akt inhibitor MK-2206 with an aromatase inhibitor. International Journal of Cancer 133 1589-1602. (https://doi.org/10.1002/ijc.28182)

Vilquin P, Donini CF, Villedieu M, Grisard E, Corbo L, Bachelot T, Vendrell JA \& Cohen PA 2015 MicroRNA-125b upregulation confers aromatase inhibitor resistance and is a novel marker of poor prognosis in breast cancer. Breast Cancer Research 17 13. (https://doi. org/10.1186/s13058-015-0515-1)

Vries ED, Venema CM, Glaudemans AWJM, Fitzpatrick L, Purandare D, Hattersley G \& Garner F 2016 A phase 1 study of RAD1901, an oral selective estrogen receptor degrader, in ER positive, HER2 negative, advanced breast cancer patients. Journal of Clinical Oncology 34 (15 Suppl) TPS627. (https://doi.org/10.1200/JCO.2016.34.15_suppl.TPS627)

Wan X, Harkavy B, Shen N, Grohar P \& Helman LJ 2007 Rapamycin induces feedback activation of Akt signaling through an IGF-1Rdependent mechanism. Oncogene 26 1932-1940. (https://doi. org/10.1038/sj.onc.1209990)

Wang X, Masri S, Phung S \& Chen S 2008 The role of amphiregulin in exemestane-resistant breast cancer cells: evidence of an autocrine loop. Cancer Research 68 2259-2265. (https://doi.org/10.1158/00085472.CAN-07-5544)

Wang Y, Zhou D, Phung S, Warden C, Rashid R, Chan N \& Chen S 2017 SGK3 sustains ERalpha signaling and drives acquired aromatase inhibitor resistance through maintaining endoplasmic reticulum homeostasis. PNAS 114 E1500-E1508. (https://doi.org/10.1073/ pnas.1612991114)

Williams JK, Wagner JD, Li Z, Golden DL \& Adams MR 1997 Tamoxifen inhibits arterial accumulation of LDL degradation products and 
progression of coronary artery atherosclerosis in monkeys. Arteriosclerosis, Thrombosis, and Vascular Biology 17 403-408. (https:// doi.org/10.1161/01.ATV.17.2.403)

Yardley DA, Ismail-Khan RR, Melichar B, Lichinitser M, Munster PN, Klein PM, Cruickshank S, Miller KD, Lee MJ \& Trepel JB 2013 Randomized phase II, double-blind, placebo-controlled study of exemestane with or without entinostat in postmenopausal women with locally recurrent or metastatic estrogen receptor-positive breast cancer progressing on treatment with a nonsteroidal aromatase inhibitor. Journal of Clinical Oncology 31 2128-2135. (https://doi. org/10.1200/JCO.2012.43.7251)

Zhang C, Guo S, Yang L, Liu J, Zheng S, Zhong Q, Zhang Q \& Wang G 2017 Metabolism, pharmacokinetics, and bioavailability of ZB716, a
Steroidal Selective Estrogen Receptor Downregulator (SERD). Oncotarget 8 103874-103889. (https://doi.org/10.18632/ oncotarget.21808)

Zucchini G, Armstrong AC, Wardley AM, Wilson G, Misra V, Seif M, Ryder WD, Cope J, Blowers E, Howell A, et al. 2015 A phase II trial of low-dose estradiol in postmenopausal women with advanced breast cancer and acquired resistance to aromatase inhibition. European Journal of Cancer 51 2725-2731. (https://doi.org/10.1016/j. ejca.2015.08.028)

Zwijsen RM, Wientjens E, Klompmaker R, van der Sman J, Bernards R \& Michalides RJ 1997 CDK-independent activation of estrogen receptor by cyclin D1. Cell 88 405-415. (https://doi.org/10.1016/S00928674(00)81879-6)

Received in final form 27 February 2018

Accepted 12 March 2018

Accepted Preprint published online 12 March 2018
() 2018 Society for Endocrinology Published by Bioscientifica Ltd. Printed in Great Britain 